Title:

\title{
A Rat and Its Redactors: Silent Co-Authorship in Kalīla wa-Dimna
}

Author(s):

\author{
Beatrice Gruendler
}

Document type: Postprint

Terms of Use: $\quad$ Copyright applies. A non-exclusive, non-transferable and limited right to use is granted. This document is intended solely for personal, non-commercial use.

Citation: 


\section{Beatrice Gruendler}

\section{Freie Universität Berlin}

\section{A Rat and Its Redactors: Silent Co-Authorship in Kalīla wa-Dimna ${ }^{1}$}

Kalīla wa-Dimna is at the same time one of the most popular premodern books and a pioneering work of Arabic literature in several ways: first, it has two layers of meaning, one overt and one hidden which has to be decoded by the reader; second, it displays a sophisticated framing structure with replaceable modular elements, which makes it easily adaptable to new cultural contexts; third, it is one of the earliest Arabic books and reflects on how books are to be read and how their content is to be applied in real life. Finally, it is one of the most frequently illustrated books of Arabic literature and speaks about the function of illustration in one of its prefaces. ${ }^{2}$

Above all it is a cosmopolitan work. From its Sanskrit origins, it traveled to Europe and Asia, via an intermediate Arabic phase, and it became the most widely spread European medieval text. The archaeologist James Henry Breasted, founder of the Chicago Oriental Institute, once described it as, "an ancient text which, next to the Bible, has become the most widely distributed and translated book in the entire history of literature," and he made it one of the pilot projects of his Institute, created in 1919 with the support of John D. Rockefeller as "a laboratory for the study of the rise and development of civilization." ${ }^{3}$ But this remained a prelude to an unfinished edition.

The Arabic version of Kalīla wa-Dimna is the direct or indirect source of all later translations, the point of departure of its global dissemination, and all research on its subsequent textual history must engage with it. However, the quest to untangle the torturous textual history of this version is as complex as the book itself. The extant witnesses of the Arabic version or, more correctly, versions, vary to such a degree that any expectation of reconstructing an "original" is unrealistic, and indeed no critical edition has been accomplished to this day. Inversely, the work's textual history offers a prime example of mutable and fluctuating written transmission, which is remarkable for a book that once belonged to the $a d a b$ corpus of classical Arabic literature and was counted as a model of eloquent

\footnotetext{
1. This publication has been made possible via the Kalīla and Dimna - AnonymClassic research project at Freie Universität Berlin, funded by an Advanced Grant of the European Research Council (ERC) within the European Union's Horizon 2020 research and innovation programme under grant agreement No. 742635 (www.geschkult.fuberlin.de/en/e/kalila-wa-dimna/index.html). I thank the members of the team for their comments on an earlier draft of this paper. Preparatory research has been supported by an E-Learning/E-Research of the Center for Digital Systems (CeDiS) of Freie Universität Berlin. Both have used the LERA digital edition tool, developed in the SaDAProject at Martin Luther University Halle-Wittenberg (sada.uzi.uni-halle.de) with support from the German Ministry for Education and Research (BMBF).

2. See Beatrice Gruendler, "Les versions de Kalïla wa-Dimna: une transmission et une circulation mouvantes," in Énoncés sapientiels et littérature exemplaire: une intertextualité complexe, ed. M. Ortola. Nancy: Éditions Universitaires de Lorraine 2013, 385-416. For introductions to the work, see François de Blois, Burzoy's Voyage to India and the Origin of the Book of Kalilah Wa Dimnah, London: The Royal Asiatic Society, 1990, Ulrich Marzolph and Heinz and Sophia Grotzfeld, "Kalīla und Dimna," Enzyklopädie des Märchens, vol. 7 (1993): pp. 888-95, and Carl Brockelmann, "Kalīla wa-Dimna," Encyclopaedia of Islam, new (second) edition, 4 (1974), pp. 503-6 (first publ. 1929). On the Arabic translator-redactor, see István T. Kristó Nagy, La pensée d'Ibn al-Muqaffa': Un "agent double" dans le monde persan et arabe, Paris, Éditions de Paris, 2013 and Michael Cooperson, "Ibn al-Muqaffa'," in Arabic Literary Culture, Dictionary of Literary Biography, vol. 311, London: Thomson Gale, 2005, pp. $150-63$.

3. James H. Breasted, "The Oriental Institute in Chicago - a Beginning and a Program," American Journal of Semitic Languages and Literatures 38.4 (1922): 233-328, esp. 314-19 ("The Tales of 'Kalīla wa-Dimna' and the Ancestry of Animal Fables").
} 
prose. As centuries went by, the book's classical Arabic register became more and more hybridized in some manuscripts (although the precise degree of non-classical features varies in each), and its content was transformed in multiple ways. The purpose of this essay is to trace these transformations.

Moreover, Ibn al-Muqaffa' (d. 757/139), the Arabic translator-redactor of Kalīla wa-Dimna, has all but disappeared behind repeated rewritings. We can no longer tell what he himself may or may not have composed in the mideighth century, because his words have been overwritten by countless later copyist-redactors, many of whom did not sign their names. It once belonged to the most widespread texts of premodern times. It is a classic, but its authorship has become obscure or anonymous, even though we glimpse here and there the name of one Fulān b. Fulān who declared his name (not his interference) in a colophon, such as Hasan al-Rabbāt, the owner of a library of popular literature in Aleppo at the turn of the nineteenth century. ${ }^{4}$ To attempt a conventional critical edition of Kalīla wa-Dimna is not only pointless but would ignore and distort its eventful textual history.

This work is therefore the site of manifold polarities: between Ibn al-Muqaffa' and his competing anonymous coauthors, between Classical Arabic and Middle Arabic, and between rationality and triviality. Regarding its authorship, there were no true authors to begin with; the book began as a translation from Middle Persian, in which it was already a selection, redaction and translation of anonymous and mutable Indian works (Pañcatantra and Mahābhārata). This made it even easier to pull Ibn al-Muqaffa' off his authorial pedestal, and in fact most Arabic sources refer to Kalīla wa-Dimna as Kitāb al-Hind, eclipsing Ibn al-Muqaffa' altogether. One famous French descendent, which served as a model for the fables of Jean de La Fontaine, is attributed to "le sage Pilpay." 5 This is none other than Baydabā', the philosopher telling the Indian king instructive fables in the frame tale, and who is turned into the author of the entire book. Such an attribution is similar to declaring Shahrazad the author of the 1001 Nights.

This essay can offer only a preliminary diagnosis of the textual problems and a proposal for their solution, because research on Kalila wa-Dimna has shown that unexpected puzzles lay hidden at each turn. For instance, the relations among the manuscripts vary from chapter to chapter and even within the same chapter, as does the degree of proximity (or distance) between the manuscripts. Therefore, until the totality of extant specimens has been surveyed and compared, one must refrain from generalizing on initial and partial findings. ${ }^{6}$

\footnotetext{
4. This library (which was turned into a lending library by the owner's descendants) has recently been reconstructed by Boris Liebrenz; see idem, "The Library of Ahmad al-Rabbāț: Books and their Audiences in 12th to 13th/18th to $19^{\text {th }}$-century Syria," in Marginal Perspectives on Early Modern Ottoman Culture: Missionaries, Travelers, Booksellers, ed. U. Pietruschka and R. Elger, Halle, 2013, pp. 17-59 and Ibrahim Akel, "Aḥmad ar-Rabbāt: Sa bibliothèque et son rôle dans la réception, diffusion et enrichissement des Mille et une nuits," doctoral thesis, Littératures, Université Sorbonne, Paris Cité, 2016

${ }^{5}$. After the French translation of Gilbert Gaulmin, Le livre des lumières ou la Conduite des rois, composée par se sage Pilpay indien, traduit en français par David Sahib d'Isfahan (1644). See Jean de La Fontaine, Fables, préface de JeanCharles Darmon, dossier et notes par Jean-Charles Darmon et Sabine Gruffat, Paris: Librairie Générale de France, 2002, pp. 203 and 473 (another French version of the sage's name is Bidpaï). Baydabā' is also given as author on the title pages of some Arabic manuscripts. The later preface of Alī b. Shāh tells the story of Baydabā composing the book for the Indian king, which is ahistorical, since the redaction and the title derive from the Middle Persian phase. However, the appearance of Baydabā' as an author and narrator within the work has certainly contributed to crediting him as its author.

6. Many of the phenomena bear comparison with manuscript variation in medieval European literature as treated in the following recent studies: R. Howard Bloch, Alison Calhoun, Jacqueline Cerquilini-Toulet, Joachim Küpper, and Jeanette Patterson, eds., Rethinking the New Medievalism, Baltimore: Johns Hopkins University Press, 2014;
} 
There are several ways to access the text of Kalīla wa-Dimna; namely, one may choose from (in chronological order) its indirect transmission, beginning with the ninth century, its translations in Europe and the Near East, starting in the eleventh century, and complete manuscripts of the work, extant since the thirteenth century. Each of these paths is paved with surprises and, paradoxically, although this work appears to be well known, the closer one looks at it, the less familiar it becomes. Here I will take the third path, to wit, complete Arabic manuscripts.

Any investigation of Kalīla wa-Dimna necessarily relies on the foundational studies by Sylvestre de Sacy (who produced the first European printed edition), Carl Brockelmann, ${ }^{7}$ and Theodor Nöldeke. ${ }^{8}$ A pioneering step was taken by Martin Sprengling in 1924 with his attempt at a conventional critical edition and reconstruction of the original, which Theodor Nöldeke at the time called "a colossal task." But this project was not carried to term, and subsequently, as Christine van Ruymbeke formulates it, "the enormous excitement for the early discoveries around the extant versions of the text in several cultural and linguistic areas came to a brutal standstill several decades ago," which she ascribes to "disappointing results" and an "overly-complicated field." ${ }^{9}$ The state of scholarship has hardly moved forward since then. Robert Irwin ${ }^{10}$ had described the problem in 1992 in the same manner, "Its [i.e. Kalīla wa-Dimna's] text was not treated with respect by copyists and adaptors... it has so far proved impossible to reconstruct the exact text written by Ibn al-Muqaffa'." Although Sprengling fell short of his main goal, he identified the sequence of the chapters as a parameter of classification. The number of chapters is relatively stable, but Sprengling found six different sequences in which these occurred, which he labelled A - F. ${ }^{11} A$ further sequence has since been discovered, which I label G. ${ }^{12}$ François de Blois finally edited the short version of Burzoy's voyage (one of the prefaces) from a number of manuscripts, and presents a useful survey of dated and undated manuscripts preserved in European libraries. $^{13}$

In the current state of research on this manuscript tradition consisting of drastically differing versions, only a synoptic critical digital edition of selected specimens can do the work justice, juxtaposing and comparing versions and investigating them in their received forms without any attempt at reconstruction. The goal is not to turn back the wheel of time, but rather to document the history of the text in its preserved state, and to analyze the context and factors of its textual development. On this basis, an array of further questions arises: how can a work change so

Stephen Nichols, ed., Speculum special issue, "The New Philology," 65.1 (1990); and Bernard Cerquiglini, L'éloge de la variante: Histoire critique de la philologie, Paris, 1986.

${ }^{7}$. His survey of the worldwide spread of Kalīla wa-Dimna (see note 2) has yet to be superseded.

${ }^{8}$. For his many articles, which are still valuable today, see the bibliography.

${ }^{9}$. Christine van Ruymbeke, Kashefi's Anvar-e Sohaili: Rewriting Kalila wa-Dimna in Timurid Herat, Leiden and New York: Brill, 2016, p. 321.

10. Robert Irwin, “The Arabic Beast fable," Journal of the Warburg and Courtauld Institutes 55 (1992): 36-50.

11. Martin Sprengling, "Kalīla Studies," American Journal of Semitic Languages and Literatures 40 (1924): 81-97. See also a short description of the sequences in Gruendler 2013, 397-98 and 726 below.

12. This is MS Paris, BnF, arabe 3475, dated 1175/1761, in which the chapters deriving from the two Indian sources (Pañcantantra and Mahābhārata) are dovetailed with each other.

${ }^{13}$. See de Blois, Burzoy's Voyage, pp. 66-72. 
much and remain simultaneously the same? How exactly did it change? Who changed it? And why?

However, before these larger questions are broached, the textual witnesses must be surveyed and two immediate issues must be resolved: first, how do the manuscripts relate to each other? And second, what is unique and specific about each manuscript? These initial questions have been explored here, based on a small sample, in an attempt to refine them and discover every possible aspect of comparison in this fluctuating tradition. Only then can the larger questions about the reasons for this variation, its connection with the work's linguistic register (shifting between classical Arabic and Middle Arabic) and the agency behind it be addressed.

In the following one should bear in mind that the variation of Kalīla wa-Dimna is the result of mainly written (not oral) transmission ${ }^{14}$ and that one cannot automatically privilege some manuscripts over others based on their earlier dating, since even the earliest ones are separated by five centuries from the Arabic translator-redactor. Conversely, late manuscripts may be based on lost versions from several centuries prior. In comparing a selection of manuscripts below, their relative chronology was therefore not considered an a priori factor, since their dating need not necessarily coincide with that of the versions they contain. Nonetheless early manuscripts are still important, since they give the ante quem for the redactions they contain.

\section{The manuscript sample}

The seven Arabic manuscripts investigated here represent a sample from the circa one hundred extant specimens so far identified. They were selected based on their early date, their distribution among different chapter sequences (according to Martin Sprengling's classification ${ }^{15}$ ) and their substantial amount of rewriting, ${ }^{16}$ since the goal was to arrive at a maximum of variation to detect as many types of changes as possible. The following early manuscripts (13th to 15th century) were consulted:

Istanbul, Ayasofya 4095, the earliest known manuscript, dated 618/1221 ${ }^{17}$, chapter sequence $\mathrm{C}$ var., copyist 'Abdallāh b. Muḥammad al-'Umarī (abbreviated hereafter as A4095).

\footnotetext{
${ }^{14}$. Scant evidence of oral telling has been found so far, such as one instance of the narration of selected enframed tales (oral communication of Heba Tebakhi, 28.3.2019). Indeed manuscripts such as Paris, BnF arabe 3593, which only contains selected subtales, may have served as a repertoire for oral retelling (for a list of the tales, see Réné Basset, "Notice sur un manuscrit des fables du Kalilah et Dimna," Journal asiatique, série 9, tome 16, 1900).

15. See note 10 .

${ }^{16}$. For the purpose of this analysis, those manuscripts that agree verbatim with some used here (and which must, with potentially intervening lost copies, derive from the same Vorlage) have been excluded. Nearly identical are P3465 with MS Munich, Bayrische Staatsbibliothek, Cod. arab. 615 and Rabat, Royal Library of Morocco 3655 with Paris, BnF arabe 3475. P5881 is likewise nearly identical with MS Istanbul Ayasofya 4214 and MS Cairo, al-Maktaba IMarkaziyya li-I-Makhțūtāt al-Islāmiyya 1169. MS Montreal, McGill University Library, McLennan no. 94 is similar to Wetzstein II 672, while MS Riadh, King Fayșal Library 2407 and P3473 are less close but still share most units with it. Such closer resemblances appear only among a minority of the manuscripts inspected so far, though their exact proportion remains to be assessed. More common is the case that a manuscript shows a clear overlap with others while exhibiting more or less evidence of individual rewriting. Such rewriting is moderate for instance between MS Beirut USJ 00022(2) and P3466 but extensive between MS Tunis Bibliothèque nationale de Tunisie 2281 and P3466.

17. Ibn al-Muqaffa', Kalila wa-Dimna, ed. Ṭ. Husayn and 'A. 'Azzām, Cairo: Dar al-Ma'ārif, 1941. Although it is a critical edition, it contains unacknowledged interventions by the editor, for which reason the manuscript has been consulted instead.
} 
Paris, Bibliothèque nationale de France, arabe 3465 (P13), ${ }^{18}$ dated by Bernard O'Kane ${ }^{19}$ to the thirteenth century based on its illustrations, chapter sequence $A$. The beginning and end of the manuscript have been lost and restored (hereafter P3465).

Paris, Bibliothèque nationale de France, arabe 3466 (P1), dated to 854/1450 based on a reader's note (which is only an ante quem) with unfilled spaces for illustrations, chapter sequence D (hereafter P3466).

London, British Library, Or. 8571 (L1), dated 799/1369, chapter sequence C var. Kalīla wa-Dimna is followed by an emulation of it in verse, entitled al-Ṣādịh wa-I-bāghim, by Ibn al-Habbāriyya (d. 509/1115-16; hereafter L8751).

London, British Library, Or. 4044 (L5), dated by Charles Rieu to the fifteenth century, illustrated, chapter sequence A var., Kalīla wa-Dimna is followed by Sulwān al-muțā by Muḥammad b. 'Abdallāh b. Ẓafar alȘiqillī, (d. 565/1169 or 568/1172), ${ }^{20}$ written in the same hand. The beginning and end of the manuscripts are missing (hereafter L4044).

Regarding these manuscripts, the label "early" is relative, since even the oldest extant textual witnesses fall half a millennium after the original Arabic version. For all purposes, whatever Ibn al-Muqaffa"s pen produced must be considered lost, and the proliferating textual tradition overwriting him up to the nineteenth century is to be studied in its own right. The intervening "dark period" from the mid-eighth to the early thirteenth century may be filled in partly by fragmentary indirect transmission and by the translations. Although both require their own specific approaches, one major source of indirect transmission from the tenth century has been adduced here as an early point of orientation. 21

Two later manuscripts (from the seventeenth century) have been added for comparison with the early group, because upon inspection they likewise exhibit substantial rewriting:

Paris, Bibliothèque nationale de France, arabe 5881 (P6), dated 1092/1681, chapter sequence C, illustrated (hereafter P5881).

Paris, Bibliothèque nationale de France, arabe 3473 (P7), dated 1110/1699, chapter sequence $B$, with the script alternating between three colors and containing legends of illustrations but no spaces for the illustrations themselves (hereafter P3473).

The rewriting of Kalīla wa-Dimna continued with verve during the eighteenth and nineteenth centuries. The ever increasing degree of narrative and linguistic variation (extending into the dialectal register) in inspected manuscripts (Paris, Bibliothèque nationale de France, arabe 3478 with unfilled blanks for illustrations and dated to the 18 th century, and Berlin, Staatsbibliothek, Wetzstein II 672, dated 1246/1830, with marginal legends but no spaces for

\footnotetext{
18. These sigla refer to the commented list of manuscripts in de Blois, Burzoy's Voyage, 66-72.

19. O'Kane, Bernard, Early Persian Painting: Kalila and Dimna Manuscripts of the Late Fourteenth Century, London: Tauris, 2003.

${ }^{20}$. A mirror consisting of beast fables (like Kalīla wa-Dimna) but also historical anecdotes, composed in 545/1150 and dedicated to Abū 'Abdallāh Muḥammad al-Qurashī, qā'id of Sicily. For a recent study, see Francesca Bellino, "Animal Fables in the Sulwān al-muțā' by Ibn Zạar al-Siqillī," in Mirella Cassarino, ed. Islamic Sicily: Philological and Literary Essays, special issue of QSA N.S. 10 (2015): 103-22.

21 . See note 24 .
} 
illustrations ${ }^{22}$ ) requires a separate investigation, because this accelerated redaction process needs to be placed within the context of changing sociocultural parameters, such as an increased readership and the rise of authorship in segments of the population below the educated elite. ${ }^{23}$

\section{The sample chapter}

For comparing the manuscripts, the short chapter of "The Cat and the Rat" has been chosen. ${ }^{24}$ It belongs to the block of three tales deriving from the Mahābhārata ${ }^{25}$ and lends itself to analysis because the manuscript evidence is extremely diverse, and the chapter also figures prominently in one of the most copious sources for the work's indirect transmission, the Muḍāhāt amthāl Kitāb Kalīla wa-Dimna bimā ashbahahā min ash 'ār al-'arab by al-Yamanī (d. 400/1009). ${ }^{26}$ This chapter seems to have been of particular interest for later readers; the topic of instrumental, or strategic, friendship aroused visible reactions, as copyist-redactors added, cut, or changed significant portions of the text.

But lest we take the second step before the first, a brief summary is in order: like most other chapters of Kalīla waDimna, "The Cat and the Rat" opens with a frame dialogue between an Indian king (Dabshalīm and variants) and a philosopher (Baydabā' and variants), in which the king requests an example of a situation in which a ruler is surrounded by enemies and verging on perdition, and he prevails by concluding a pact with one of them and honoring it.

In response, the philosopher tells a story in which a rat, cornered by an owl and a weasel, seeks refuge with a cat, who is himself caught in a hunter's net nearby. The rat proposes a pact of mutual help and survival: if the cat spares the rat and offers him protection, the rat will gnaw through the ropes confining the cat. So it comes to pass. The cat

22. This is an autograph by the owner of a library in Damascus; see Liebrenz, "The Library of Ahmmad al-Rabbāț," 19 and 27-28.

23. See Dana Sajdi, The Barber of Damascus: Nouveau Literacy in the Eighteenth-Century Ottoman Levant, Stanford, California: Stanford University Press, 2013 reviewed by Jeffrey Sacks, "The Philological Present: Reading the Arabic Nineteenth Century. Review Essay of Four Books," Journal of Arabic Literature 47 (2016): 169-207; Nelly Hanna, In Praise of Books: A Cultural History of Cairo's Middle Class, Sixteenth to Eighteenth Century, Syracuse, New York, 2003; and Konrad Hirschler, The Written Word in the Medieval Arabic Lands; A Social and Cultural History of Reading Practice, Edinburgh: Edinburgh University Press, 2012.

${ }^{24}$. It is found in the manuscripts on the following folios or pages: A4095 fols. 223v,17 - 226v,4; L4044, fols. 97v,4 101v,2; L8751, fols. 41v,11 - 44r,2; P3465, fols., 117r,3 - 120r,6; P3466, pp. 273,13 - 282,16; and P5881, fols. 79v,3 $81 \mathrm{v}, 1$.

${ }^{25}$. Within the Mahābhārata, they belong to Book XII "The Book of Peace," which marks a moment of retardation after the great battle between the Kaurava and Pānḍava families. In it the hero Yudhișțira, pierced by so many arrows that his body rests on the arrows' shafts when he is laid down, spends a year giving moral instruction to King Bhìsma and persuades him not to abandon the throne to become an ascetic but to shoulder his duties as a ruler; for a synopsis, see Moris Winternitz, Geschichte der indischen Literatur, Leipzig: Amelangs Verlag, 1909, vol. 1, pp. 259403, esp. pp. 315, 348-62, and 363. The Mahābhārata reached its final form between 400 BCE and 400 CE and constitutes a conglomerate of literary genres whose compositional entity is still a matter of debate; see Madeleine Biardeau, Le Mahabharata, 2 vols., Paris: Seuil, 2002.

${ }^{26}$. Ed. Muhamammad Yūsuf Najm, Beirut: Dār al-Thaqāfa [1961]. This partisan of pure Arab lore was irked by the popularity of Kalīla wa-Dimna and felt impelled to show that its parables (amthāl s. mathal) and wise sayings (hikam s. hikma) had antecedents in early Arabic poetry. In the process of juxtaposing both, he cites 165 passages from the book. 
agrees and assists the rat, and the rat fulfills his own part - not without some delay however, and the versions differ as to the rat's motivations for the delay. Finally both animals escape to safety. True to the book's original purpose as a mirror for princes (Fürstenspiegel), there is a follow-up to the tale of mutual rescue, explaining the underlying principle of strategic friendship, i.e., friendship that is conditional, useful, and temporary. As soon the danger has passed, the cat calls the rat back, assuming that their newly concluded friendship will last, but the rat informs the cat that this is not so. The rat has already explained in the second dialogue that there are two types of friendship $\left(43^{27}\right)$, the first serving a purpose, and the second purpose-free. Here the rat labels the present case as the first type: their friendship was formed out of a need, which has ended, and therefore the friendship is over, having fulfilled its goal. The rat further explains that any outward friendship from the cat can only be hidden enmity, and the sole use the cat may have for him is as food (73). The rat therefore tersely bids the cat "Goodbye" (82 in P3473 and P3466). In L4044 alone, the rat elaborates: "The gist of the matter, which is the last word (wa-l-jumlatu Ilatī yanqați u 'anhā I-manțiq), is that no path leads to reunion lest a catastrophe occur like the one which previously brought you and me together."

\section{Macroanalyis}

To comprehend and assess the manuscripts' full scope of variation, the analysis of the narrative is conducted on two levels. The divergence is too large for an immediate close-up look. Instead one first needs to obtain a bird's-eye view of the narrative structure. The tale is thus observed in its overall composition, and only then do we take a detailed look at the formulation within each element. At the first level of analysis, the sample chapter has been subdivided into meaningful segments (eighty-five units in total, of which the minimum appearing in a single manuscript is fortynine, in P3465, and the maximum is seventy-two, in L4044, which translates into a difference of three and a half folios of thirteen lines vs. four and a half folios of fifteen lines). This subdivision takes account of the framing structure and the diverse ingredients of the narrative, namely:

- frame dialogue (abbreviated in fig. 1 as " $\mathrm{fd}^{\prime \prime}$ ),

- third-person narrative within the fable (“n”),

- interior monologue ("ml") or dialogue ("d") of the characters,

- analogical images ("m" for mathal ${ }^{28}$ ) and maxims ("ḥ" for hikma) used by a character to illustrate a point, and

- paratexts, such as the title of the chapter's fable, presented within the frame dialogue (" $t$ "), preceding abstract, final summary, and commentary (all "g"), and the chapter's closure phrase ("tm" for tamma "the end"). ${ }^{29}$

27. The numbers refer to the semantic units into which the text has been divided for alignment in the XML/TEI files upon which the synoptic edition is based. See the list in fig. 1 below and the distribution of the units across the manuscripts in fig. 2.

${ }^{28}$. In this work, the word mathal, pl. amthāl, means both "parable" and "analogical image"; other meanings are "proverb" and "example," all of which share the basic meaning of analogy.

${ }^{29}$ Already the copyists noticed these structural elements, as many manuscripts mark inquit formulae and beginnings of subtales by colored ink, overstrike, or paragraph symbols (colored dots, inverted apostrophes, or parallel oblique lines). The modular structure of the text obviously prompted such copyists to flag salient passages. 
The story is related mainly through direct speech. In an initial monologue, the rat meditates on his precarious situation (units 12-16), then follow four dialogues: in the first (17-31), he proposes the pact to the cat, in the second (36-50), he motivates his delay in severing the cat's ropes, in the third (54-55), he announces that the time for fulfilling his commitment has come, and in the fourth and longest (59-82), he explains to the cat the principles of strategic friendship. The following chart (fig. 1, on the next two pages) shows the plot's units (listed by their XMLtags), their type (according to the above list), and their distribution in each of the seven analyzed manuscripts.

Fig. 1. Comparative chart of text units in the chapter of "The Cat and the Rat" in seven manuscripts. [Double page, place at next page break]

At this scale, P3465 and, to a lesser degree, P5881 lack a number of units, which may

be the result either of abridgment in these manuscripts or lack of expansion as in other manuscripts. ${ }^{30}$ In all manuscripts, the variation is strongest at the chapter's end, where a number of units appear in only few of the manuscripts $(74,78,80,81,85)$. Regarding the number and sequence of units, P3465 in particular differs from the rest by being much shorter and by placing right at the beginning the rat's explanation of his self-protection to the cat, namely leaving one last rope intact until the hunter's arrival (30). Then he begins to gnaw through the cat's ropes (34), at which point the owl and the weasel leave disappointed (33). In all other manuscripts, the rat proposes another strategy, that of displaying their friendship (29), so the cat should show joy at the rat joining him (32), at which point the rat's other foes leave frustrated (33). The self-protection follows here as part of the rat's subsequent strategy, which is moved to the second dialogue and serves for his defense when the cat complains about the rat's slowness in gnawing though the ropes $(46,50)$.

Also evident is the lack of anything one might term "groups." ${ }^{31}$ Even in the large-scale comparison, no manuscript shares all units with any other. Rather, some manuscripts (the four last cols. on the right in fig. 1: A4095, L8751, P3466, and L4044) share a body of units to which unique ones are added in most cases. The overall impression is that of a fluctuating and cumulative process, which I describe as a redactional continuum.

The cumulative trend is visualized in fig. 2, which locates the manuscripts on a chart showing their total amount of units (horizontal axis) and the proportion of their units that they share with other manuscripts (vertical axis). For instance, the short and idiosyncratic P3465 is on the lower left and shares few units with other manuscripts, whereas the long and inclusive P3466 and L4044 are on the upper right.

\footnotetext{
30. Abridgment seems more likely, since some of the units absent in P3465 appear in the tenth-century work of alYamani $(21,39,70,74,75)$, as do the some of the units absent in P5881 (15, 74 and 76).

31. This term has been used by Martin Sprengling (see note 10) to classify manuscripts by their sequence of their chapters. However, on close inspection the chapter sequence does not tally with the relative similarity (or difference) between manuscripts based on shared text units. The designation of the sequence has been retained as merely one factor of classification and is recorded in fig. 1, line 2. Sprengling's assertion that sequences $A$ and $C$ dominate among Arabic manuscripts has so far proved true.
} 
Fig. 2. Chart of shared text segments in the chapter of "The Cat and the Rat," in manuscripts of Kalīla waDimna. [Full page]

Fig. 3. Chart of shared text segments in Ibn al-Muqaffa's preface of "The Purpose of the Book," in manuscripts of Kalīla wa-Dimna.

The particular continuum in the sample chapter, however, cannot be generalized to the full manuscripts under investigation. In this chapter, A4095, L8751, P3466, and L4044 are closer to each other than to the remaining manuscripts, the situation is different in Ibn al-Muqaffa's preface. There two continua appear, but one is constituted by P3465, P3473 and 3466 (which is referred to as the "Paris continuum"), whereas the remaining manuscripts form another (see fig. 3). P3466 thus changes from one continuum to another between chapters, which poses the question of whether copyists routinely used several Vorlagen and switched between or combined them. So far several manuscripts indeed show a combination of two Vorlagen within one same chapter, ${ }^{32}$ but the modalities of combination vary, and the question requires further investigation.

A third phenomenon is that most manuscripts ${ }^{33}$ show unique units at different points, which means that individual copyists selectively expanded the tale. These unique units per manuscript are extracted here from fig. 1 and arranged by type:

\begin{tabular}{|c|c|c|c|c|c|c|}
\hline & P3465 & P3473 & P5881 & L8751 & P3466 & L4044 \\
\hline $\mathrm{n}$ & 30,47 & 35 & & & 26,41 & 56 \\
\hline $\mathrm{ml} / \mathrm{d}$ & 54 & & 19,60 & & & 31 \\
\hline $\mathrm{m} / \mathrm{h}$ & & 48 & & & & 27,77 \\
\hline $\mathrm{g}$ & & & 83 & 84 & & 1 \\
\hline Total & 3 & 2 & 3 & 1 & 2 & 6 \\
\hline
\end{tabular}

Most of these units add more detail to the action or speech to the characters, although new analogies, maxims, and paratexts appear as well. L4044 stands out by containing twice as many instances of rewriting as any other manuscript.

32. Ayasofya 4213 juxtaposes two versions of one unit in the preface of Ibn al-Muqaffā', introducing the second by wa-qïla, which is explicit and intentional. In MS Riadh, King Fayșal Library 2536, in the preface of Ibn al-Muqaffa', folio 5 is written in a different hand (perhaps a later restoration) and follows a different version. Since the two Vorlagen derive from two different continua which differ substantially even in the sequence of units, the switch leads to many duplications and was clearly unintentional. In P5881 in the long voyage of Burzoy (Lv), passages resembling A4095 and other resembling P3466 are intercalated within a number of units, among them two different analogical images on the theme of guarding secrets, which are respectively unique to either Vorlage. This is intentional cross-copying in order to maximize the facets of the narrative at each step. In another case, MS München Bayrische Staatsbibliothek 616 a second expanded version is noted on the margins, partly resembling P3466 and L4044 and partly unique to this manuscript. MS Oxford, Bodleian Library, Pococke 400 likewise shows signs of cross-copying.

${ }^{33}$. Except for the oldest dated manuscript, A4095. 
In terms of the distribution of the changes across the chapter, the synopsis of units (fig. 1) shows the greatest fluctuation in the fourth dialogue, in which the rat explains the difference between a friendship concluded by choice versus a friendship induced by outer forces. He further explains why the second type of friendship necessarily ends when these forces have ceased, and the situation has changed. Scribal intervention intensifies surrounding this controversial topic: what is friendship? Can it be instrumentalized? These questions necessarily generate different answers, based on the situation to which they are applied. A strategic pact between rulers is guided by a different set of morals than a personal relation between individuals, and according to the context in which a particular copyist between the thirteenth and the seventeenth century understood the fable, his implicit verdict varies.

Returning to the immediate questions posed in the introduction, the macroanalysis has helped to refine the first of them. In the search for the interrelationships between the manuscripts, one cannot discern any discrete groups but rather a fluid development in which each specimen marks a point along a process of accretion, excision, and reformulation, a sort of mouvance par écrit to adapt a term Paul Zumthor has coined for oral medieval French literature. ${ }^{34}$ As to the second question, the bird's-eye view shows that there exists a unique quality to most manuscript versions in the form of certain text segments that occur nowhere else. ${ }^{35}$ To proceed further, the changes within each of the units now need to be observed close up.

\section{Microanalysis}

The following analysis was aided by the alignment of corresponding text segments in the different manuscripts with the synoptic LERA-tool, ${ }^{36}$ which allows easy comparison across all manuscripts and immediately shows the different amount of text per segment in each specimen.

At first glance, the formulation of P3465 within shared units is often shorter than elsewhere. At times P3465 merely provides a kernel of text that is integrated into a longer passage in the other manuscripts (notably 63 and 69, and to a lesser degree $34,40,57)$. Identical phrases recur through many manuscripts in multiple combinations, but often phrases appearing in either P3473 or P5881 are contained in both P3466 and L4044 (e.g., 11, 20, 69, 71, 75). In these units, the accretion is additive from P3473 or P5881 via A4095, L8751, and P3466 to L4044, for which reason the manuscripts have been ordered in this sequence from left to right in the chart, since this shows the cumulative process of redaction. The continuum from A4095 to L4044 (hereafter called the "London continuum" after the location of two of the manuscripts) tends to reunite formulations that appear scattered among other manuscripts. The pair of P3466 and L4044 at the right end is most inclusive in assembling a majority of units extant in diverse other specimens (although both manuscripts also contain much unique material, as will be shown).

In terms of the interrelationships between the manuscripts, the microanalysis across all units confirms the results of the large-scale view, namely that of a redactional continuum in which formulations fluctuate. The amount of change within the different units is not stable and constant but varies considerably. There are some in which the text changes little, although full verbatim identity across all manuscripts is rare. Where it does occur, it often results from a binary syntactic or semantic figure (parallelism, antithesis) whose tight structure stabilizes the formulation. In

\footnotetext{
34 Paul Zumthor, Essai de poétique médiévale, Paris; Éditions du Seuil, 2000, pp. 84-96 and 610.

${ }^{35}$. The designation of such passages as unique remains preliminary, because parallels may appear in manuscripts still to be inspected.

${ }^{36}$. On LERA, see note 1 . The manuscripts displayed there were transcribed and digitized by the team of Kalīla waDimna-AnonymClassic.
} 
other units, massive rewriting occurs, especially in those essential to the chapter's main message - and it is characteristic of fables to include their own commentary. This selectiveness of the rewriting process proves that the intervention of the copyists was intentional and targeted and not random or thoughtless.

\section{Types of changes}

In surveying the changes the text undergoes, one needs to separate the intentional changes from the unintentional ones as much as possible. Among the latter, besides copyists' errors, homeoteleuton recurs in passages with repetitive formulations. ${ }^{37}$ Here I will focus on intentional, i.e., redactional changes, which substantially affect the text in the chosen chapter. Rewriting within the units can best be shown by example, for which one scene has been selected, namely that in which the rat, having assessed his situation, approaches the cat to propose a joint strategy. It is unit 20, labeled "Rat describes common problem", and counts among the strongly fluctuating units of the fable (see fig. 4).

Fig. 4. Synoptic edition of unit 20, "Rat describes common problem" based on seven manuscripts of Kalīla wa-Dimna. The color key on the lower left shows their interrelation. Grey shading marks passages identical in all MSS; shades of blue mark select correspondences between specific manuscripts as indicated; magenta shading marks passages limited to one MS only. Particles have been disregarded, as they cannot be unequivocally assigned. [Full page, rotated 90 degrees]

In this unit, every manuscript has been compared with every other, and a total of nineteen different types of correspondence appear, but only the most frequent relationships of similarity have been marked in color. Passages shared by all manuscripts (marked in grey) are relatively few. A greater portion is taken up by passages shared by some manuscripts (marked in shades of blue according to the key in the graph; for instance, light blue marks passages coinciding from left to right in all manuscripts from P3473 to L4044, i.e., columns b to g). A substantial portion of some manuscripts is constituted by those passages that appear in only one manuscript (marked in magenta).

These unique passages represent either altered or added formulations (from single words to full sentences). These "edits" can be subdivided into five types:

- Synonymous paraphrase

- Reformulation with a changed sense, although through minor alterations

- Reinterpretation or adaption of the consonantal skeleton (rasm), yielding anything from a paraphrase to the introduction of a new meaning with more or less rewriting to contextualize it.

- Proliferation of the text through the rephrasing or combination of elements that appear elsewhere in the same chapter

- Substantial addition of entire phrases or sentences in which the copyist most visibly acts as a silent co-author.

\footnotetext{
${ }^{37}$ Another is the phenomenon of repetitio, i.e. the reuse of a prior word where another is logically expected. This has been described by John Dagenais in medieval Spanish scribal practice; see idem, The Ethics of Reading in Manuscript Culture: Glossing the Libro de buen amor, Princeton New Jersey: Princeton University Press, 1994, pp. 132-34.
} 


\subsection{Synonymous paraphrase}

This type occurs in the rat's opening statement. Surrounded by foes, he seeks the help of the cat, who is caught in the hunter's net. The rat wants to propose that the cat shelter him, while he himself bites through the cat's fetters. But first he must establish trust and convince the cat of his sincerity. The words he uses differ in the manuscripts, though the sense remains essentially the same (portions unique to one manuscript are marked bold):

I am sincere ... these words of mine contain no lie or deception (P3465)

$$
\text { مخلّصًا وكلامي هذا لبس فيه كذب و لا خديعة أنا[ـA] }
$$

You will know that my words to you are neither false nor foolish.

(P5881).

$$
\text { وستعلم [مقالتي للك ] إنّها ليست بزور ولا باطل }
$$

I am speaking to you without lying (P3466).

إنّي أحتّثك حدينًا لا أكنب فيه

These edits show that copyists also deemed the style of their Vorlage (not only the content) worthy of improvement and felt free to reformulate passages as they saw fit.

\subsection{Reformulation with a changed sense}

The variety of ways in which this can occur is without limit, and the following example from this unit serves merely to show one of many possibilities. In four manuscripts (in P3466 this is slightly reformulated), the rat describes his gloating at the cat's misfortune as a former attitude that he no longer holds:

What harmed you used to bring me joy, and I used to consider your confinement

to be my freedom, but today ... (A4095/L8751/P3466/L4044)

كان يسرني ما ساءك وأرى ما ضيّق عليك لي سعة ولكنّي اليوم ...

In P3473 however, the same sentence is negated and slightly expanded to make it apply to the rat's present feelings towards the cat:

I am sad about what harmed you, and the confinement I see you in gives me no freedom or peace (P3473[A2]).

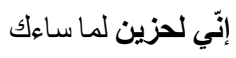

وما أر اه من الضيقة عليك ليس بسعة ولا راحة عليّ

Through the shift, the rat's new feelings (of sympathy) are given more weight than his former ones. 


\subsection{Reinterpreted or adapted consonantal skeleton (rasm)}

This type of change is specific to the Arabic script. Its pre-conditions are several: to begin with, the reductive script (an alphabet of the abgad type) does not note short vowels. ${ }^{38}$ Furthermore, the script used in Arabic manuscripts is reductive to a higher degree than that of modern print, because these manuscripts do not consistently include diacritic dots on homographs. This may reduce the number of graphemes from twenty-eight to as few as twentytwo. Manuscripts may further dispense with several symbols that have become typographical standards. First, the glottal stop (hamza) is mostly omitted. This is a consonant in classical Arabic and is only represented by a supralinear sign (not a letter) in the Arabic alphabet. In manuscripts it can be indicated by the madda sign, if following a long $\bar{a}$ (alif mamdūda), or it can be replaced by a glide $(w, y)$ if placed between two different vowels. Elsewhere it is completely left out. Thus, the letter alif can stand either for the glottal stop or the long vowel $\bar{a}$. Second, the doubling of consonants (marked in modern print by the supralinear shadda sign) is often left unmarked. These aspects of reduction and polysemy work together in allowing varying readings of an Arabic manuscript, especially in view of the vast vocabulary of classical Arabic, which was a formal idiom of high prestige, mastered fully only by the educated. At the same time the abgad system was conceived for Semitic languages with their characteristic relationship between lexical root and morphological pattern, in which the completion of unwritten short vowels and case endings was governed by rules.

Reading Arabic script is therefore an interactive process in which one needs to supply what is missing on the page, but this is easy to do (in most cases) by someone familiar with the written Arabic language. As a result, a premodern user of Arabic manuscript codices would be accustomed to reading contextually and filling in the gaps left in the written form. Such a contributive kind of reading differs fundamentally from the reading of a more fully phonetic alphabet such as Spanish or German in Latin letters. ${ }^{39}$ To a reader with limited competence in classical Arabic, however, this posed problems, and one may argue that it was precisely the incomplete grasp of classical Arabic by some of the later copyists that spurred the reinterpretation of the script and concomitant alterations in the text, made in order to recontextualize such readings that had altered the meaning.

In this light, the fact that, in many literary genres and scholarly disciplines, the texts of Arabic manuscripts remained relatively stable is remarkable, and this stability is owed to well-established conventions of teaching and transmission and to the scholars and professional copyists who upheld them. The present work, however, being sui generis as a manual of statecraft presented as a collection of fables, slipped from high adab to the popular register over the centuries and therewith moved beyond the reach of scholarly control.

As a result, the contextual reading and completion, which the compact Arabic script required from the copyists of Kalīla wa-Dimna, encouraged them to rethink their Vorlagen unchecked by scholars. In particular, the copyists'

\footnotetext{
${ }^{38}$. For the function and applications of this writing system, see Beatrice Gruendler, "Stability and Change in Arabic Script," in: The Shape of Script: How and Why Writing Systems Change, ed. S. Houston. Publications of the School of Advanced Research, Santa Fe, 2013, 93-118.

${ }^{39}$ To be clear, Arabic script has the inbuilt option to render a text fully phonetically. Yet this was exercised in texts to a varying degree, according to the text type, its readership, or the commissioning patron. In manuscripts of Kalīa wa-Dimna, diacritics and vocalization likewise range from being both fully present (e.g. in P3465) to almost completely absent (e.g., in L4044).
} 
different readings of the consonantal skeleton (rasm) produced everything from synonymous to diverging (or illogical) interpretations of a written passage and even to the introduction of completely new ideas. This type of change further proves that alterations happened though rewriting, as opposed to oral retelling. ${ }^{40}$

In some cases, such reinterpretation produces a cognate meaning; in others, however, it gives a sentence a new focus, such as the alternative interpretation of a word's rasm, such as ba's (بأس) "courage" or ya's (يأس) "despair" depending on the addition of one dot underneath the first letter. Within its context, this rereading affects the motivation for cooperating with an enemy. What reads in P3465 (4) as "The intelligent man uses . . . a strategy . . . which is intrepidity towards his enemy and kindness towards his friend" (wa-dhū l-ra'yi yuḥdithu ... ra'yan . . . ammā min qibali l- 'aduwwi fa-bi-l-ba'si wa-ammā min qibali-șadīqi fa-bi-l-isti'nās) reads in L4044 inversely as ". . . when one desires something from the enemy and despairs of something from one's friend" (. . 'inda l-țam 'i fimā qibala l-'aduwwi wa-l-ya'si bimā 'inda l-șadīq). With the addition of one dot, the word is changed from "intrepidity" to "despair" and reassigned from describing the attitude shown the foe to that shown the friend. Moreover, the alternative options of behavior towards friend vs. foe in P3465 become simultaneous in L4044. The process may have begun with a misspelling, but the adjustment of the surrounding particles to make sense of the reread rasm shows the scribe's intention. Such multistep developments could only occur in the absence of a scholarly transmission of a text, which would reign in alterations at every step of copying or dictation.

When a reinterpretation or adaption of the rasm causes a change of meaning, this may prompt further conscious and deliberate interventions by a copyist-redactor in order to fit the newly generated meaning into the context. One case such occurs in the unit in which the rat explains his strategy of self-protection (46). Having been saved, the rat is taking his time in gnawing through the cat's nets, and the cat complains, suspecting him of defaulting on his promise. The rat defends himself with the need to protect himself, being the weaker party. Here one rare word, alja'ani (past tense verb in the IV. stem of the root I-j-' "to seek refuge" with suffix pronoun), is open to interpretation, because the letter alif lacks the hamza sign marking its function as a glottal stop (') as opposed to long $\bar{a}$. The below formulation of the rat's statement occurs thus (or similarly) in the majority of the manuscripts:

I am keeping my word to you, while guarding myself lest the very thing which made me have recourse to a truce with you happen to me[A3]... (P3466/L4044) ما هو ألجأني إلى صلحك

In P5881 the same segment is reformulated and the word is analyzed as al-jāni (definite article and the active participle of I. stem of the root $j-n-y$ "to harvest"):

I am keeping my promise to you, while protecting myself from incurring that which happened to him who harvested fruit at the wrong time (P5881).

ما أصاب الجاني للثمر في غير وقته

\footnotetext{
${ }^{40}$. So does the alternation between verbatim or closely identical passages with others that are completely
} rephrased or newly added, as mentioned in section 4 above. 
The new meaning of "the harvester" (al-jānī) is followed by the unique addition of a phrase that makes sense of this and leads to the creation of a new unit, the "Ill-timed harvest." Here the copyist has heeded the context well, for his addition fits with the following unit, namely the maxim: "Everything has its time."

In the two previous examples, the new reading occurs without any changes to the rasm itself. In other instances, however, not only are diacritics and additional signs changed (or missing ones supplied differently), but letters are also mistaken for others that look similar in the manuscript hand. One such case appears in the example unit (20). Most manuscripts use the following phrase to explain the rat's willingness to cooperate with his sympathy for the cat's sorry state. It contains the word 'ațtafani (past tense verb in the II. stem of the root 't- $f$ "to empathize with"):

This has softened me towards you (L4044).

عطّقني ذلك عليك

What softened me towards you is ... (P3473/A4095/L8751/P3466)

الذي عطّني عليك

However, in P5881, the copyist has disregarded the small loop of the letter $f \bar{a}$ ' and read the script as $a$ 'ținī, an imperative of the verb "to give" (from the IV. stem of the root ' $-t-w$ ).

"Grant me that pact [of protection] from you" (P5881). فأعطني ذلك عليك

The Arabic basic text (rasm), the economy of the manuscript writing, and potentially a less than clear hand of a Vorlage have permitted this reading, particularly if the diacritic dot on the letter $f$ is left out, as is the case in L4044. The new reading fits neatly into the narrative, but it alters the rat's attitude by giving him a demanding and forceful speech, as opposed to his show of empathy elsewhere.

Another creative instance of adapted rasm occurs at the moment when the rat finds himself surrounded by foes and tries to keep his sangfroid (12). In a number of manuscripts (A4095/L8751/P3466/L4044) he decides that he will not allow his "mind to go to pieces (شعاعًا)" lā yadhhaba 'aqlī shu'āan). In the manuscript Berlin, Wetzstein II 672, dated 1830, the rat's mental process is detailed further, and the reinterpretation of the rasm gives rise to a metaphor: "I will make the ray (شعاعه) [of my ratio] shine upon my heart" (aj'alu shu 'āa ahū [sc. 'aqlī] 'alā lubbī."

A semantic change of even wider proportions occurs in Ibn al-Muqaffa"s preface, in the passage (121) describing the four goals of Kalīla wa-Dimna as a book. To wit, the book's third goal, as formulated in P3465, is to be a companion for kings (li-yakūna unsan (أنسًا) li-qulūbi l-mulūki), and therefore it must be made more attractive with illustrations. In later manuscripts the relevant word unsan (thus in the accusative) is reread as nis $\bar{a}$ ', and the contemplation and enjoyment of pictures is now attributed to kings' consorts instead, as in P3466 (li-takūna qulūbu nisā'i (نساء) I-mulūki amyalu ilayhi), and Paris 3473 further adds kings' pages to the avid beholders of pictures (li-takūna qulūbu nisā'i (نساء) I-mulūki wa-ghilmānihim ilayhi amyalu). ${ }^{41}$ This description of the audience of illustrated books deserves further study and comparison with reading practices contemporary with these manuscripts (fifteenth and seventeenth centuries). ${ }^{42}$

\footnotetext{
41. In P3473 this passage has been moved under the first goal.

${ }^{42}$. See as an example Hirschler, The Written Word.
} 
Such rereading may even ignore word boundaries. An extreme example occurs in the passage about the two types of friends, the true and the strategic (43). In several manuscripts, the salient point is that the behavior of the strategic friend depends on the circumstances aḥwāl (أحوال), such as in P3465 (wa-ammā l-muḍțarru fa-fi ba'ḍi lahwwāli yastarsilu wa-fï ba ḍ̣ihā yata azzazu), L4044 (wa-ammā l-muḍțarru fa-inna lahu hāatatun (sic) yustarsalu ilayhi fihā wa-ukhrā an yuḥtarasa minhu fïhā), and P3466 (wa-ammā l-muḍțarru fa-inna lahū hāalāni (sic) ${ }^{43}$ yustarsalu ilayhi fihā wa-hālāni yuttaqā fîhā). Inversely P5881 takes "compelled" (muḍtarru) to refer not to the foe turned temporarily into a friend, but to the other party, who is caught in an unpredictable relationship with him. The remainder of the sentence is partially reformulated so as to emphasize the need to use utter caution (wa-ammā $I$ muḍțarru fa-inna [la]hū ahaqqu allā yațma'inna ilayhi [fīhā]). Herein the word aḥwāl is read as two words, namely as ahaqqu allā (أحقّ ألّا liable not to [feel secure]“). The prepositional phrases lahū and fihā are remnants of the previous formulation and no longer make sense, but the copyist failed to adjust them to the new reading. Here again, we may be dealing with a confluence of intuitive reinterpretation and redactional intervention. The latter is obvious in the copyist's cutting the alternative behaviors towards a strategic friend, taking account of the fact that the meaning of "circumstances" had disappeared in the new reading of the rasm.

In some cases, however, a rereading seems to veil an earlier meaning. For instance, in the same passage, which contrasts the true friends and the strategic friend (43), the designations for the former in the manuscripts vary between "the eager friend" (الصديق الطامع al-șadīq al-țāmic; P3465) and "the compliant friend" (الصديق الطائع alịa al-țā'ic; A4095/L8751/P3466/L4044), neither of which seems to the point, since the opposite is described as "the compelled friend” (الصديق المضطرّ al-șadīq al-mudțarr; P3465). In this case the indirect transmission, preserved in the tenth century Muḍāhāt ${ }^{44}$, provides the answer to the puzzle with "a friend by his character, a true friend" (șadīq alțibā' as opposed to "a friend by compulsion" (صديق الطبق sadīq al-iḍtirār).

The indirect transmission also provides the answer to another puzzle. In a passage that shows the risks of a strategic friendship (76), most manuscripts designate the risk one incurs by trusting a strategic friend too quickly as leading to a "misstep, stumbling" ('athra عثرة; lā tuqālu 'athratuhū, P3465; lā yakādu yustaqbalu 'athratuhū, L4044; lā yakādu yastaqīlu 'athratahū, P3466). The solution comes from Muḍāhāt, whose older reading explains the action to be feared from a strategic friend more logically as a "calamity" (ghāila غائلة ; lā tu'manu ghā'ilatuhu). Curiously, the later manuscript P3474, dated 1761, restores the sense by reusing the word "rage" ${ }^{45}$ from P3465: lā yakādu yaslamu sar'atahü). This and the previous case of slightly awkward readings look like a copyists' best guesses at a less than clear Vorlage.

Instances of such adaptation and reinterpretation of the rasm occur regularly in Kalîla wa-Dimna, but some manuscripts, such as P5881 and L8751, contain significantly more cases than others, which may be a consequence of those copyists having either less legible Vorlagen or a freer attitude towards them.

\subsection{Proliferation of the text through the recombination of elements and syntactic dilation}

The text can be expanded by reusing and slightly reformulating passages from other places in the same chapter.

Thus, the text of L8751 grows through internal recombination. In Ibn al-Muqaffa"s preface, the element of amazing

${ }^{43}$. The accusative word hălan has here been rewritten as the dual hăăāni, a pseudo-correction.

${ }^{44}$. See note 24 above.

45. The morphological form șar'a occurs only in Middle Arabic; see Reinhart Dozy, Supplément aux dictionnaires arabes, 2 vols., Leiden: Brill 1881, reprint Beirut: Librairie du Liban 1991, s.v. 
ignorance is (as in other manuscripts) part of the analogy of a man who continues to travel along a wrong path and fails to recognize his error (35). In L8751 such ignorance is repeated in a new unit that describes readers who misunderstand the deeper meaning of the book (46). This and similar cases in this text show a palpable tendency to grow by internal recombination.

A salient case in L4044 is a unique unit containing a brief summary, introducing the "Cat and Rat" chapter (1). This takes its formulation from the subsequent frame dialogue between the king and the philosopher (16). Elsewhere in this manuscript (when compared with the earlier A4095), words and phrases are inserted in a way that affects the syntax and changes the causal connections. The impression is that of a growing mosaic. For instance, in the long analogy of a man memorizing a sheet containing elements of Arabic grammar (19), L4044 adds a clause describing the learned assembly (wa-fïhi jamā'atun min ahli al-iilmi wa-l-fașāha) in which the ignoramus embarrasses himself. Further below, a maxim (75) is rephrased and placed in the mouths of scholars (77). ${ }^{46}$ This type of accretion emphasizes points that are already stated in the text but strengthens them by reiteration.

\section{Substantial additions and trends of rewriting}

The last type of change, substantial addition, is best shown throughout an entire chapter in selected manuscripts, since it is the sum of editorial interventions that need to be viewed in context. In the following, the versions of the "Cat and Rat" chapter in those three manuscripts that contain the largest amount of rewriting (both within shared units and by adding new units) are analyzed in detail. While the basic storyline remains intact and some formulation is shared, the identified interventions develop the tale in each case in a different direction, and they do so consistently throughout this chapter. This shows clearly that most of the changes were not the random products of a careless copyist, but rather deliberate acts of redaction. ${ }^{47}$ Even within this short chapter, the visible interventions (whether these be cumulative or individual) can be shown to engage with the tale in an authorial manner. However, it cannot be ascertained whether this was the doing of the very copyist to whom we owe a particular version or his Vorlage or a combination of the two (i.e., individual or cumulative redaction) until all extant manuscripts have been compared.

\subsection{P5881 - Emotion and Drama}

The text portions that are unique to P5881 expand the chapter's emotional and dramaturgical aspects. Unlike other versions (and unlike early Arabic narrative, which focuses on outward action), the characters' inner feelings are spelled out, such as the cornered rat's confusion (wa-baqiya mutahayyiran fi amrihī wāqifan lā yadrī kayfa yașna iu, $\left.{ }^{48} 11\right)$, the cat's joy at the proposal (fa-fariḥa bi-dhālika farahan 'aẓiman, 28), and, at the tale's end, the rat's fear for his soul (wa-ana akhāfu 'alā rūhī minka wa-min 'adāwati mā baynī wa-baynakā, 71).

\footnotetext{
46. See section 6.3 for a discussion of this example in the context of the chapter.

${ }^{47}$. For the argument that specific passages were selected for rewriting, whereas others remained more or less intact, see sections 4 and 5.3 above.

${ }^{48}$. Bold words within a quote are those unique to one manuscript. Words set in Roman style also appear in other manuscripts and are reused in P5881 even though at times in a changed context. The numbers refer to the units in which this occurs; bold numbers indicate entire units unique to the manuscript under discussion. For a list of units, see fig. 1.
} 
The dialogue is also made livelier with added changes of speaker, and the characters' direct speech is expanded. In the rat's monologue, he wishfully thinks that the cat might cooperate (la 'allahū... yusallimu bi-dhālika li-șulhī, 16) and decides right from the start to be frank with his foe (qāla l-juradhu wa-Ilāhi lā akdhibuhū shay'an mimmā fi damīī, 19). In his address to the cat, the rat is forceful, demanding the cat's commitment outright (fa-a'țini dhālika 'alayka, $20^{49}$ ). In the fourth dialogue, he immediately interrupts the cat's invitation with a refusal (qāla lahū Ijuradhu lā sabilla ilā l-dunuwwi minka, 60), before he explains at length later on why he can no longer remain in the cat's company. The cat similarly receives more expressive lines; when he swears not to harm the rat, he invokes God as his witness (wa-ashhada 'alā nafsihī llāha subhānahu wa-ta'ālā 'alā dhālika, 63). This version accentuates the opposition between friend and foe. The friendship is recalled merely as a thing of the past (wa-hiya [al-hājatu] Ilatī aḥdathat . . hādhihī I-șadāqata wa-qad maḍā, 71) and then placed in an antithesis with enmity (tahawwala șafā'uhū 'adāwatan, 69). Toward a friend one is always amenable (wa-ya'malu lahū jamīa mā yurīduhū, 43), whereas with a foe one must be permanently on guard (fa-inna lahū ahaqqu allā yațma'inna ilayhi fihā, $43^{50}$ ). The rat ends apodictically: never will he trust the cat again (fa-lā ațma'innu ilayka abadan, 73).

The rewriting of the maxims likewise brings out the contrast between friend and foe: a virtuous person has the moral duty to help if he is able to do so (wa-laysa yajmalu dhālika bi-I-karīmi wa-lā yalīqu dhālika wa-lā yanbaghī an yuqașșira fi hạjjati șāḥibihī in kāna muqtadiran 'alayhi, 37). In another maxim it is not the action of treachery that is punishable (as elsewhere) but the person of the enemy (wa-a'jalu l-'uqūbati 'uqūbatu l-'aduwwi, 40 ${ }^{51}$ ). Conversely a person who cannot keep a friend will be rejected by all his friends (rafadahū ahlu mawaddatihī, 62). The distinction is clearest in the maxim bearing upon the diverse treatment of friend and foe in other manuscripts. P5881 drops the part about the friend and advises the manipulation of the foe alone (wa-idhā khāfa l-'aduwwa

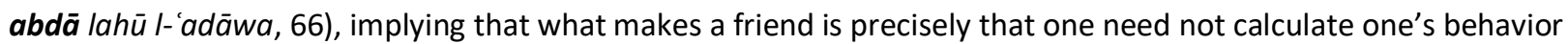
towards him.

The version concludes with a unique unit that returns to the frame dialogue between the king and the philosopher, and the latter comments that man should heed the example of a weak, tiny rat who foresaw the consequences of things and saved himself by initiating and honoring an agreement with his enemy. The philosopher ends with a direct exhortation to the reader to apply this lesson (fa-kayfa bi-l-insāni lawi qtaḍā bi-dhālika wa- amila fíhi bimā yalzamuhū min ḥusni l-naẓari . . y ya'khudhu bi-awfā nașībin minhu fi 'ājili l-umūri wa-ājilihā fa-fham dhālika wadabbirhu turshad, 83). ${ }^{52}$

On the whole, the redaction of P5881 makes the fable more entertaining and applicable for regular people, not only rulers or courtiers. The characters' speech is livelier and their emotions expressed so that the reader can identify with them. It is a version that speaks to the situation of any human being and is not geared to the courtly realm or the political arena.

\footnotetext{
49. This case of an adapted rasm is discussed in section 5.3 above.

${ }^{50}$. Adapted rasm; discussed in section 5.3 above.

${ }^{51}$. Adapted rasm.

52. A similar final commentary appears at the end of the chapter of the King of the Mice (Km), which appears in the older Syriac version but only in a few Arabic manuscripts.
} 


\subsection{P3466 - Ethics and Power}

This version focuses on ethics, relations of power, and how the characters negotiate between these in their interactions. The gravity of the situation is emphasized by envisioning failure.

In the rat's monologue, he dwells on his position of strength (Iā yastațíu ahadun an yukhallișahū ghayrī, 16), and sees the potential benefit of the cat as a means of increasing his own power (wa-la'allahū . . yațma'u fi ma 'ünatī . . . wa-yușālihuni li-naf 'i nafsihī, 16). This idea is then broached directly to the cat: the rat alone has the power to set him free (laysa aḥadun aqdaru 'alā ma ūnatika wa-takhlīṣika min hādhihī l-warțati minnī, 20). In return, the cat must accept a pact not to kill the rat (fa-in anta ammantani wa- 'ähadtani allā taqtulanī, 20). The rat stresses that only mutual help can save both of them (kadhālika bi-l-ta āwuni minnī wa-minka narjū l-khalāṣa min hādhihi lbaliyya, 26), and thereafter an added sentence informs the reader of the pact's conclusion (fa-ta'āhadā 'alā dhālika, 28).

When the cat later demands the rat's fulfillment of the pact by adducing a maxim, he implies that he has fulfilled his own part and the rat has obtained his share of the deal (fa-laysa hādhā l-karīmu ${ }^{53}$ bi-khalīqin an yatawānā fi hājati șāhibihi idhā huwa qaḍā hạajata nafsihī, 37). The cat further applies a parallelism to his own and the rat's situation, reiterating the rat's owed reciprocation (kamā asra 'tu ana fi khalāșika wa-ma ūnatika fa-kadhālika anta ḥaqīqun bi-l-ijtihādi fi khalāṣi min hādhā l-withāq, 41). When the rat then explains that he must protect himself, he recalls his situation of power, reminding the cat that he never had a choice (mā huwa alja'anì ilā șulhika wa-aljā'aka ilā qubūli dhālika minnī, 46).

Conversely, the cat's weak stance is adumbrated with added narrative detail: at the hunter's approach, he senses his imminent death (fa-lammā ra'āhu [sc. al-șayyāda] istash 'ara l-halakata, 53), and the oath he swears not to harm the rat in the future contains a protestation of sincerity (wa-jtahada 'alā l-șidqi fímā qāla, 63).

Cat and rat impersonate weakness and strength respectively. But in the maxims, the redaction gives particular attention to the weaker party by foregrounding the ethical aspects. Thus in a maxim that condemns betrayal and the denial of mercy, a second part is further specified: if the supplication comes from a sufferer or sinner, and the addressee has the power to forgive but refuses to do so, he thereby violates a code, namely, the "ethics and deeds of the righteous" (wa-man idhā taḍarra'a ilayhi l-malhūfu aw . . a al-mudhnibu . . lam yaghfir wa-huwa yajidu ilā dhālika sabīlan wa-innahü ${ }^{54}$ laysa bi-ḥāfiẓin akhlāqa l-șāliḥina man lā yaimalu a 'mālahum, 40). This is an ethics that supports the weak: it accords them rights and makes the powerful responsible for upholding and protecting these.

In addition to the behavior of an individual towards different types of friends, this version adds the sense of safety enjoyed with a true fried vs. the constant fear of a strategic friend (fa-ammā l-țā' i'u . . yu'man 'alā kulli ḥālin waammā l-muḍțarru fa-inna lahū . . h hālāni ${ }^{55}$ yuttaqā fïhā, 43). Here the concern is safety from other people as opposed to any relationships between them, as in P5881. In the maxim about losing a friend, friendship is highlighted by hendiadys (al-așdiq $\bar{a}^{\prime}$ wa-l-ikhā', al-ikhwān wa-l-așdiqā', 62), but friendship is made coextensive with usefulness in the subsequent parallelism (idhā zālati I-ḥājatu llatī ḥamalathu 'alā dhālika zālat ṣadāqatuhū, 69).

The ideas foregrounded in this version are power and ethical behavior toward the weak, and how both are

\footnotetext{
${ }^{53}$ Misspelling of li-l-karīmī.

54 Pleonastic conjunction wa- before the protasis, a feature of Middle Arabic.

${ }^{55}$. Pseudo-correction for the accusative singular hālan, a feature of Middle Arabic.
} 
negotiated. This redaction turns the fable into a tale of moral vs. political strategy in which mutual commitments are paramount, and ignoring them comes at the risk of censure or death. The message thus stays close the book's original concerns of a Fürstenspiegel but makes its teachings apply to regular people as well.

\subsection{L4044 - Character vs. Fate}

In L4044 the fable is turned into a conflict between fate and inborn character traits, in which the function of the animals as placeholders for humans becomes particularly real. It is narrated from the vantage of protagonists who see themselves thrown into a struggle between destiny and their own characters. Furthermore, this version acquires a psychological dimension by creating tension between the protagonists' inner feelings and outward actions.

In the monologue, the rat expresses his own wishes and wonders how the cat will react to his proposal, imagining the cat's emotions and thoughts: "He will realize the benefit of what I describe and ask him to do" (qāla fi nafsihī . . . la 'allahū law qad sami a mā urīdu an ukallimahū bihī . . wa-lā mimmā kariha wa-lā taqrī'an . . wa-ya'rifu manfa 'ata mā așifu lahū wa-ad ūhu ${ }^{56}$ fa-la 'allahū yațma 'u fí ma ūnatī iyyāhu fí khalāșihī fimā yajnī, 16). Of the two characters, the rat is given the greater emotional complexity. He asks the cat to consider the situation and requests not only a guarantee (as elsewhere) but a solemn oath to save the rat's life in the process of saving his own (fa-in anta ammantanì wa-ḥalafta wa-ja áalta lī an tamna 'ani ${ }^{-57}$ mimmā tamna a bihī nafsaka . . qața tu hibālaka, 20). The cat remains unidimensional. He believes the rat right away (qāla li-l-juradhi innaka 'alā qawlika fawran lā ashukku fi șidqika 'indi fihi, 28) and, upon the rat's explanation of the procedure, the cat readily agrees to the pact ( qāla l-sinnawru af'alu dhālika wa-ni'ma, 31). When explaining his delay strategy, the rat motivates this with his past and present fear of the cat (ana wāfin laka . . wa-muhtarisun minka ma'a dhālika min haythu akhāfuka ${ }^{58}$ an yușībani minka mithlumā takhawwaftuhū, 46). This is a very different rat from the one demanding a commitment in P5881 or flaunting his power in P3466.

As the hunter approaches, the cat expects to die (fa-lammā ra'āhu istaslama li-l-mawt, 53) but the rat promptly announces and executes the fulfillment of his part of the deal (wa-qāla l-juradhu hādhā l-waqtu Iladhī akhkhartu Iahū qaț a l-silki, 55; wa-akhadha l-juradhu fi qaț i l-silki, 56), showing himself to be reliable at the moment of the cat's despair. When the cat later calls the rat back, as the danger is past, he swears eternal gratitude and specifically rules out any betrayal on his part for all future time (fa-'innaka mā baqītu fa ${ }^{59}$-lā takhāfanna minnī ghadran, 63). However, this is exactly the kind of promise that a natural enemy cannot keep, according to the logic of this version. The rat lays out the dangers of such duplicity in a long unique passage within the fourth dialogue: outward protestations that hide opposite feelings constitute an enmity of the worst kind. Here the rat introduces the concept of inborn enmity:

He who cannot prevail upon a friend (mudārāt al-khalīl) after former enmity nor treat well[A4] an enemy well (mușāna 'at al-'aduww) after a former friendship makes his friend his enemy and empowers his foe over himself. And he who pretends to give advice with his tongue while his mind harbors deceit (gishsh) is

\footnotetext{
56 The object ilayhi is missing.

57. Emendation of tamta anna in L4044.

58. Redundant suffix pronoun, a feature of Middle Arabic.

59. Redundant conjunction, a feature of Middle Arabic.
} 
the worst enemy, especially if his enmity is innate (jawhariyya). It is only necessity that compels one to conclude friendship and companionship with such a foe (64).

Natural enmity can only be temporarily suspended by the power of fate, in the form of a catastrophe that forces foes to cooperate (fa-man kānat 'adāwatuhū jawhariyya fa-laysa l-mușāḥabatu lahū bi-ra'yi l-arībi illā li-ḥājatin ilayhi, 71). Fate is introduced earlier as the cause of the whole situation (kullu dhālika ta'ti 'alayhi maqādīru bimā huwa ätin, 27). Here the opposing forces of fate and nature are weighed against each other, and the rat's character must navigate between them. Prudence dictates that one must as quickly as possible give up an unnatural friendship to which one has been compelled by fate. Although this maxim appears earlier (75), the rat restates it in L4044 in an added unique unit endowed with scholarly authority:

The learned say: The intelligent person must make peace with his powerful foe and bear humiliating himself before the foe for a good reason but shun him whenever he can dispense with him and avoid trusting him, 77).

The rat, who is aware of this, distrusts the cat's "fancy talk" and expects nothing but evil from him (wa-lā aẓunnu bika illā sharran fímā tad 'ūnī bihī ilā nafsika min lațîfi I-manțiq, 73). Safety can only be ensured by mutual distance:

To my mind, regarding my safety (mina l-salāmati lī fi nafsī) from you and your keeping of your commitment (wa-laka bi-l-wafā'i bi-'ahdika), there is nothing more judicious (ahzam) than my keeping myself at a distance from you, and likewise I see nothing safer for yourself (aslama li-nafsika) than distance from the hunter regarding your wellbeing (79).

This is the last word about a bond between unequal partners - with the only possible exception of a renewed intervention of fate similar to the one that has occurred (wa-l-jumlatu Ilatī yanqați u 'anhā l-manțiqu annahū lā sabīla ilā jtimā inā illā an tanzila nāzilatun mithlu lladhí ${ }^{-60}$ jama anī wa-iyyāka, 82).

L4044 is the only manuscript that introduces the fable with an abstract (1). This reuses text from a later unit within the frame dialogue in which the king gives the gist of the situation for which he wishes an exemplum (16). ${ }^{61}$ With its substantial additions, some of which have been cited above, it is the most sophisticated version of the three: it introduces the psychological conflict between a person's feelings and actions and situates this within the larger conflict between God's decree and human nature, which the fable translates into animal behavior. This rewriting changes the fable from a tool for teaching political strategy into a study of character in extraordinary circumstances, when the divine and natural orders collide.

\footnotetext{
60. Invariant relative pronoun, a feature of Middle Arabic.

${ }^{61}$. For this internal repetition, see also section 5.4 above.
} 
The microanalysis and particularly the survey of substantial additions have answered the second initial question regarding the unique and distinctive features of each manuscript. It is indeed fascinating in how many ways the copyist-redactors manage to reinterpret the character of the rat in only three versions of this chapter, namely, as provocative (P5881), powerful (P3466), or conflicted (L4044). It remains to be seen whether the emphases on drama, strategy, and psychology visible in this chapter extend throughout these manuscripts in their entirety, so as to give each version of the book a consistent trend. Such a detailed study of the full manuscripts remains to be undertaken.

\section{Linguistic and codicological aspects}

The results of the preceding (partial) narratological analysis need to be placed in the context of the whole manuscripts, both in their textual and material aspects as well as their combination with other works in multiple text manuscripts. This comprehensive view can only be sketched out here, and it is also limited by the incomplete state of preservation of some of the specimens.

Indications about a version's production and reception can be gathered from its manuscript's physical characteristics: visual arrangement (page layout, sequence and topics of illustrations), paratexts (incipit, table of contents, colophon, corrections, marginalia, readers' notes, ownership marks, and any unrelated notes added at a manuscript's beginning or end), and other works assembled with Kalïla wa-Dimna into a single binding (such as in L8751 and L4044). Illustrations notably take a life of their own when illuminators add characters that do not appear in the text, such as the bare-breasted women in bed with the protagonist in the substory of the pauper winning clothes from a thief (P5881, fol. 11v, chapt. Im, unit 62). It is interesting to note that, in some manuscripts, spaces for illustrations have not been filled in (P3466 and P3478), or illustration legends are recorded in the text but with no space left for the actual illustrations (P3473). The former might be a copyist's way of targeting both wealthy and less wealthy buyers and completing the illustrations only if he was paid for them, and the latter may be due to a copyist's omission of illustrations not desired by a commissioning customer, while allowing their potential reinsertion in a subsequent copy of the same manuscript. Alternatively they may have been retained to act as side titles to quickly locate a particular passage. A majority of images illustrate substories, which are thus easy to find. The fact that accessibility was a factor in the manuscripts of Kalīla wa-Dimna is also evident in the thorough subdivision and highlighting of the text in many of the manuscripts. Marked are usually substories, wisdom sayings and their elements, and the inquit formula ( $q \bar{a} l a)$ indicating a change of speaker or a return to the narrative frame. Hereafter I will limit myself to a few remarks about the incipits and colophons of the three analyzed manuscripts.

\section{1. $P 5881$}

P5881, for instance, is written in narrow-spaced, small naskh with a double frame around the text and colorful illustrations. The chapter of "The Cat and the Rat" contains two illustrations, one of the first dialogue (between 18 and 19) and another of the fourth and last dialogue (between 59 and 60), so that both images are placed immediately before a unit that is unique to this version. The joint emphasis of redactor and illustrator on these redacted passages points to their collaboration or perhaps even their identity.

The manuscript also contains an incipit before the first preface of the book (LV). After the basmala, subdivided by paragraph markers in the shape of red dots, two versions of a table of contents follow. The first is a short 
enumeration for quick reference with chapter titles (given as sixteen in total, preceded by two epistles ${ }^{62}$ ) numbered serially and written in red ink. The second is an expanded list of chapter titles with intercalated synopses of their content. ${ }^{63}$ Between both tables appears an enumeration of the book's benefits, defined as "330 types of wisdom (bāb min al-hikma)," covering everything from the correct and prudent behavior towards kings to general human virtues, including one's good deeds, present and future, the proper management of wealth, the renunciation of worldly goods, and vices from which one needs to protect oneself. No unified moral stance emerges; instead the precepts are contrastive and complementary. The framing structure of the book is pointed out as constituted by "340 intercalated stories (uḥūtha mutadākhila ba 'ọuhā fí ba 'ḍ)." The list of qualities reappears in the second and longer table of contents that follows. Each synopsis gives a chapter's a gist, general message, and particular addressees. Kings are targeted in only four of the sixteen chapters. Elsewhere, those who should follow the lessons are "the intelligent" (al-arīb, al-'āqil, dhawū l-'uqūl, dhawū l-albāb), "the knowledgeable" (dhū l-ma 'rifa, al-'ārifūn), and "people of all trades" (ahl kulli șan 'a). The chapter synopsis of "Cat and Rat," specifies no recipient at all and runs as follows:

This is the parable (mathal) of a man with many enemies who surrounded him from all sides so that he verged on perdition, and he sought rescue by befriending and concluding a truce with one of these enemies, and he [thereby] extricated himself from what he had feared. He who forms a pact with his enemy must use caution and place his trust [carefully]. This chapter indicates [the use of] strategy (ihtiyāl) when catastrophes occur and proper planning, from the beginning to the consequences.

The synopsis of the chapter of "The King and His Dreams" (Kd) contains, in addition to the above points, a literary commentary on its wisdom sayings (ta'addub balīgh fïl-dunyā wa-l-dīn). A one-line colophon records the date (1092 [1681]) but no copyist's name or place.

The language displays moderate Middle Arabic features (twelve instances within the chapter). These mostly represent cases of "relaxed grammar," such as morpho-syntactical errors, dropped particles, tautologies, and two pseudo-corrections, but no admixture of dialect. ${ }^{64}$

62. The first epistle is Lv (fol. 3v), the second is not described in P5881 (nor in Cairo, al-Maktaba I-Markaziyya 1169, a nearly verbatim copy), but Ayasofya 4214, which is another nearly verbatim copy of P5881, adds a description of the second epistle as praise of King Anūshirwān by Buzurgmihr. This forms the conclusion of the frame dialogue after the last chapter (Ag) but is not marked by any heading (fol. 91r,9). Im and Bu are each counted as chapters, so that Lo, the first parable, becomes chapter three.

${ }^{63}$ Other than the mentioned MSS similar to P5881, MS Oxford, Bodleian Library, Pockoke 400, dated to the $14^{\text {th }}$ century, contains a table of contents with intercalated synopses and is so far the earliest example. In the indirect transmission, such a table with synopses is given by al-Yaqūbī (d. 286/897) in a chapter sequence resembling D though some chapters are missing; see al-Ya'qūbī, Ta'rīkh al-Ya'qūbī qui dicitur al-Ja'qūbī Historiae, ed. M. T. Houtsma, Leiden 1883, 98-99 and al-Ya'qūbī, The Works of Ibn Wāḍị al-Ya'qūbī: An English Translation, ed. Matthew S. Gordon, Chase F. Robinson, Everett K. Rowson and Michael Fishbein, Leiden: Brill, 2018, vol. 2, pp. 35152.

${ }^{64}$. For a list of Middle Arabic features in popular Arabic literature, see Bruce Fudge's introduction, $A$ Hundred and One Nights, ed. and trans. by Bruce Fudge, The Library of Arabic Literature, New York: New York University Press, 2016, pp. xxxvi-xxxvii and Jérôme Lentin, "Middle Arabic," in: Encyclopedia of Arabic Language and Linguistics, ed. Kees Versteegh, 5 vols., Leiden : Brill, 2006-9, vol. 3, 215-24. 
This version, besides being lavishly produced, is accessible and its contents broadly applicable; it targets a wide readership and highlights the book's literary qualities. The existence of two nearly verbatim copies ${ }^{65}$ is noteworthy and infrequent among manuscripts of Kalīla wa-Dimna.

\section{2. $P 3466$}

This manuscript may have been produced with aspirations for an elite market, but its illustrations were never filled in (only the legends are written vertically on the margin next to the blanks); perhaps the eventual buyer was not willing or able to pay the added expense. Unfilled illustrations occur in a number of manuscripts and may be an indication that a more limited upscale market widened to include a less well-to-do clientele.

The basmala and subsequent text, written in a wide-spaced, artless, but legible naskh, is subdivided with paragraph markers in the form of red dots, circles, or three inverted apostrophes, and inquit formulae occasionally receive a red overstrike.

The incipit is rather brief; it motivates the book's composition and then enumerates the reasons for adding each of the prefaces: first Baydabā' composed the book overtly as a collection of animal tales in order to reserve its hidden wisdom to philosophers, who are able to decode it. Then Anūshirwān sent Burzoy to bring the book from India, which he did together with the large chess game (with $10 \times 10$ fields; this corresponds to Lv). Thereafter Buzurgmihr added a preface on the book's benefits ${ }^{66}$ and another on Burzoy himself (corresponding to Bu), placing it before the chapter of "The Lion and the Ox" (corresponding to Lo), which is the beginning of the actual book. Thereafter follows the preface written by 'Alī b. Shāh (As).

The table of contents is not given within the incipit (as it is in P5881) but inserted into As at the place where Baydabā"s composition of the original Indian version is narrated. Fourteen headings are announced and listed, though the manuscript actually contains fifteen, because $\mathrm{Km}$ (located between $\mathrm{Kd}$ and $\mathrm{Mc}$ ) is left out in the table of contents. Baydabā's procedure in the book's creation is described as ambitious and perfectionist:

Then he began to compose the book (thumma btada'a fï naẓm al-kitāb wa-tașnîfihì) without interruption. He dictated and his disciple wrote, and he altered and revised until the book turned out utterly perfect, containing fourteen chapters, each of them self-contained, and he included himself and the king and the answer[s] given to him as part of the book, so that the king would be directly addressed (pp. 25,ult. - 26,4).

The parable form and its animal characters are explained twice, before and after the list of chapters. Before the list, the book's double-layered meaning, overt and hidden (zāhir/bāțin) and its dual function of giving pleasure and conveying wisdom (lahw/hikma) are motivated as being a code for the elite (khāșșa) and the wise (hukamā') and a convention of wisdom books (ka-rasmi sā'iri l-kutubi llatī rusima li-l-hikam), and its content described as everything needed for the here and the hereafter serving kings and counseling them, and avoiding what should be avoided. The

\footnotetext{
65 . See note 53.

${ }^{66}$. As in P5881, this is does not correspond to a separately titled entity in the manuscript. Indeed, this incipit resembles the second part of the incipit of P5881, see section 7.1.
} 
table of contents itself (pp. 26,10-28,1) is highlighted in a larger red script and the chapter headings are formatted as a centered column with intercalated synopses supplying the gist of each chapter.

The language contains moderate Middle Arabic features (sixteen instances within the chapter), of the same type as in P5881 but with six pseudo-corrections.

The book shows ample traces of use (and reuse) at the end (pp. 341-44). These include reading marks, one them containing the date $854 \mathrm{AH}$ [1450 CE], which is a post quem, and unrelated texts, such as two recipes for falūniya, ${ }^{67}$ a panacea, a notice about the birth of a son, and writing exercises of Qur'ān verses. This version, too, obviously circulated among a non-elite readership.

\section{3. $L 4044$}

The case of L4044 is a puzzle because the manuscript's different aspects seem to contradict each other. The beginning with any potential incipit and the end are missing. The preserved part begins in the middle of the long version of "Burzoy's Voyage" (Lv), with another lacuna of several pages in the same section, and the text of Kalīla wa-Dimna ends without a colophon, since it is followed by Sulwān al-muțā' by Ibn Z̦afar al-Ṣiqilī (d. 565/1169 or 568/1172), which in turn lacks its last pages. This twelfth-century work is an emulation of Kalīla wa-Dimna, composed for a Sicilian military official, and the combination of both works speaks to the specific interest of the copyist or his client in the genre. ${ }^{68} \mathrm{~A}$ personal commission further fits with the idiosyncratic nature of the redaction and the spacious mise en page on large pages with wide margins. Some aspects show great care. Introductory formulae are often highlighted in a larger pen, and substories are given their own titles in larger script within the running text. Select words are highlighted with a large pen, such as the imperative "be aware" (ilam, 76), which precedes one of the redaction's unique passages (77), as if to point out what the copyist held to be particularly important. This presentation indeed suggests an educated client of some social status.

The large page format with lavish images, some on double pages, confirms the appearance of a luxury copy. However, most of the images are placed on the margins or the empty parts of title pages and might potentially be later additions. ${ }^{69}$

However, the writing, a horizontally stretched, wide-spaced and artless naskh, falls between two extremes; prose passages dispense with most diacritical dots and all vocalization, whereas verse passages (in the following work, the Sulwān al-mutā') are fully vocalized. Did the scribe target an educated reader who dispensed with such added detail? The text's language contains the same moderate amount of Middle Arabic features as the two other

67. From Greek philomena, named after its inventor Philon of Tarsus, a contemporary of Augustus, and preserved in versified form by Galen; see Dozy, Supplément aux dictionnaires arabes, s.v. f-l-y and Der Kleine Pauly, Munich, 1979, vol. 4, p. 776b, s.v. Philon.

68. The combination of Kalila and Dimna with other works, either subsequent in a multiple text manuscript or merged into one, requires a separate investigation. Remarkable is the diversity of such texts: combined with it is e.g., an emulation in verse, al-Șādị wa-I-bāghim, by Ibn la-Habbāriyya by Ibn al-Habbāriyya in L8571, an emulation in prose, Sulwān al-muțā ' by Muḥammad b. 'Abdallāh b. Zaafar al-Ṣiqillī in L4044, Pseudo-Șafadī's Law'at al-shākī in London BL Add. 23466, Ibn 'Abd al-'Td al-Mālikī's Hilyat al-kubarā' wa-bahjat al-nudamā' in Paris BnF 3476, alDamīrī's, Hayāt al-ḥayawān al-kubrā in Paris BnF 2789, the popular tale of Kal'ād and Shimās in Riadh 2407, and Alf layla wa-layla in Paris BnF 3612. Merged with Kalila and Dimna is for instance al-Tanūkhï's al-Faraj ba'da l-shidda in Beirut USJ 00022).

69. I am grateful for this suggestion to Annie Vernay-Nouri. 
manuscripts (twelve instances within the "Cat and Rat" chapter, including six pseudo-corrections) and is not conclusive. ${ }^{70}$ In terms of content, the version displays a careful reworking not only of the psychological aspects in this chapter, as shown above, but also of the epistemology of reading in Ibn al-Muqaffa"s preface (Im). Other luxurious and illustrated versions usually mark diacritics and vowels, whereas it is the simpler and less carefully executed versions with substandard Arabic features that lack vocalizations and skip some diacritics. The quality of the redaction of L4044 is in contradiction with its careless script. One explanation could be that the present manuscript is a reproduction of an earlier, more carefully executed Vorlage or an autograph by an educated writer.

\section{Envoi}

Summarizing the above, Kalīla wa-Dimna reveals itself to be a fluctuating manuscript tradition in which no groups can be detected; rather, manuscripts resemble each other (in the form of shared plot segments, as shown in fig. 1, and partial and non-contiguous places of overlapping formulation, as in fig. 3) in constellations that change throughout these manuscripts, and the use of more than one Vorlage can be ascertained in at least one case. ${ }^{71}$ Among the manuscripts, some are very inclusive ${ }^{72}$, assembling passages that appear scattered across different manuscripts, whereas others selectively abridge ${ }^{73}$ (as shown in fig. 2). In both kinds, rewriting occurs. In terms of the resemblance among the manuscripts, this ranges from drastic difference (occasional) via similarity of the macrostructure with changes within units (most frequent) ${ }^{74}$ to near verbatim identity (less frequent). ${ }^{75}$ From this textual flux, individual voices of anonymous copyist-redactors can be isolated by comparison with other manuscripts. These distinguish themselves by consistent trends of their instances of rewriting (reformulation, cuts and additions), as shown in the three examples above. This answers in part the two preliminary questions posed at the beginning.

But there is little more we can know about the redactors of the three diverging manuscripts of Kalīa wa-Dimna, examined in more detail. It appears that they were produced in different contexts and social strata, L4044 in a more educated one than P5881 and P3466. But P5881 and L4044 were costly illustrated exemplars, whereas P3466 circulated in its cheaper unfinished state and shows ample signs of use with numerous manuscripts notes. Nonetheless, in all three cases, the copyists leave their individual imprint on a chapter, foregrounding respectively drama, strategy and fairness, or fate and psychology. These copyists treated this work as an occasion to act as redactors, and they gave their versions an individual bend, even if they did not care, or dare, to declare this

\footnotetext{
70. This moderate degree characterizes the majority of manuscripts of Kalīla wa-Dimna so far inspected and must be taken as its own idiom. Thus, it is comparable to the lughat al-hikāya or lugha thālitha, defined by Muhsin Mahdi based on the earliest manuscript of Alf layla wa-layla; see idem, The Thousand and One Nights (Alf Layla wa-layla): The classic edition (1984-1994), 2 vols., Leiden: Brill, 2014, vol. 1, 45 and 47.

It remains to be seen whether the fact that this book belonged to the fable genre made a less stringent adherence to the 'arabiyya acceptable. An example of the opposite case, a manuscript in perfect 'arabiyya, is MS Rabat, BNRM 3655 .

71. See note 32 .

72. E.g., P3466, L4044, and Wetzstein II 672.

73 . E.g., P3465 and Rabat, BNRM 3566.

74 . E.g., P3473 and Wetzstein II 672.

${ }^{75}$. E.g., between P5882, Ayasofya 4214 and Cairo, al-Maktaba al-Markaziyya 1169. For a fuller list see note 31.
} 
explicitly. Why might this be? This is the place to return to the second set of larger questions posed above, which we may now refine:

Did the copyists not wish their interference to be known and rather preferred to pass off their opinions as those of Ibn al-Muqaffa' and his sources? The phenomenon of anonymity as a type of authorship and textual authority still remains to be investigated for premodern literature in general and Arabic literature in particular. Frequent are Arabic pseudepigraphica, attributed to Ancient Greek or legendary authors, especially in hermetic and magical texts. The anonymity of speciments of Kalīla wa-Dimna falls into several categories. From truncated manuscripts, missing beginning and end, nothing may be concluded. Those with colophon either lack the name of the copyist, or if mentioned, only acknowledge the mere act of copying. ${ }^{76}$ This may have translated into a higher market value, since the book was a popular classic. Even in later times, when the linguistic register and material execution of the manuscripts indicate a readership below the elite, this group continued to consider reading Kalïla wa-Dimna as an act of acquiring wisdom, ethics, and "philosophy." (This term increases in frequency with the progression of time and, paradoxically, concomitant with the relaxation of the grammatical norm and the increase of pseudocorrections and dialectal influence). Did changes in the text not matter or, rather, was it in the interest of those less educated readers to pass over the instability of the work in silence, because it allowed them to share in an ideal of education they could not otherwise reach? Did Kalīla wa-Dimna serve as a token book of wisdom for amateurs who were keen to uphold a learned status for it (that it had de facto long lost) and in the process claim the same for themselves as its users?

Or did they purposely veil what they altered out of respect for the work? Was it perhaps a stance of modesty on the part of craftsman who did not consider it fitting to call themselves (co-) authors or did not dare to declare themselves as such? The medieval translators of Kalīla wa-Dimna had no such qualms, nor did the later versifiers of the Arabic version, both of whom might even substitute their names for Ibn al-Muqaffa', and one might argue that the interventions of all three groups varied only in degree, not in kind; the Arabic version underwent a change in the linguistic register, too, since the Arabic copyist-redactors performed an intra-lingual translation, even though it is only visible as a cumulative process whose phases cannot so far be assigned to any individual agents. ${ }^{77}$

Or again, had the interference in such a text, which conveyed wisdom in the fictional guise of fables and thus drew close to popular tales, become so common that such a free treatment of the wording was self-evident and required no comment? Was authorship of such texts simply of no great relevance to their readers and (overt) originality out of place? This being said, Kalïla wa-Dimna is sui generis in its double nature as a book of wisdom and a collection of fables. It had no fixed place in the generic grid of classical Arabic literature. At its inception the component of "applied culture" (adab) dominated, and, during the book's "dark" phase up to the thirteenth century and the emergence of full text manuscripts, quotations from Kalīla wa-Dimna in works of adab mainly concern hikam, short analogical images (amthāl), and parts of dialogue bearing upon ethics and political strategy. The fable aspect

\footnotetext{
76. An exception is MS Beirut USJ 00022, which merges passages of al-Tanūkhì's al-Faraj ba'da l-shidda into the text, and the copyist declared in the colophon: "Here ends what we intended to assemble (aradnā jam 'ahū) in this book in terms of important stories and transmitted tales, so that it may let us attain important stations (fol. 191r).

77. An intriguing case is the copyist of London BL 3900, who claims authorship through ingenious cross-copying. He merges his incipit with the preface of Ibn al-Muqaffa', whose title and author he suppresses, so that the first person voice of the latter becomes his own. To achieve this, he switches between two Vorlagen, taking the incipit from Riadh 2536, itself close to Sultan Ahmed III 3015, an augmented retranslation from the Persian version by Monshi, and the Im chapter from Oxford, Pococke 400).
} 
functioned as a cover and a literary device; al-Yamanī, in his counter-text to Ibn al-Muqaffa; denigrated this aspect as "stuffing" and cut out all narrative passages. From the time of the book's fully documented state in the thirteenth century, the fictional character dominated, as is also visible in the frequency and choice of illustrations, which mostly depict enframed tales. Its language, with a more or less pronounced presence of substandard features (Middle Arabic), likens it to popular literature. ${ }^{78}$ As time progressed, an opposite trend surfaced in some manuscripts, beginning in the fifteenth century, namely a refocusing on the book's ethical and "philosophical" purport. ${ }^{79}$ This Janus-headed book was flipped back to its original focus, yet the social context and reading public had expanded into less educated strata and are still in need of further investigation.

This initial foray can only raise such and other questions, and full answers need to await a fuller survey of the eversurprising textual history of Kalīla wa-Dimna, including the conditions of its production and reception and the work's place in the shifting landscape of classical and popular Arabic literature (whose boundaries it muddles) between the thirteenth and nineteenth centuries. What is clear however, is that "classical" and "popular" should be seen as endpoints of a spectrum with many shades in between, which Kalīla wa-Dimna, as an unruly classic and a text on the move, helps to throw light upon.

Fig. 5 Paris, Bibliothèque nationale de France, arabe 5881, fol. 2v. Incipit with short table of contents. [Full page]

Fig. 6 Paris, Bibliothèque nationale de France, arabe 5881, fol. 79v. Beginning of the chapter of "The Cat and the Rat." [Full page]

Fig. 7. Bibliothèque nationale de France, arabe, p. 26-27. Beginning of the table of contents including the synopsis of the sixth chapter, "The Cat and the Rat," within the preface of 'Alī b. Shāh. [Full page, rotated 90 degrees, combine right and left half NB it is not the same opening]

Fig. 8. Paris, Bibliothèque nationale de France, arabe 3466, pp. 273-74. Beginning of the chapter of "The Cat and the Rat" with unfilled blank for an illustration. [Full page, rotated 90 degrees, combine right and left half, halves from same opening]

Fig. 9. London, British Library, Or. 4044, fols. 97v - 98r. Beginning of the chapter of "The Cat and the Rat." [Full page, rotated 90 degrees, cut black margins]

\footnotetext{
78. A few manuscripts, however, remain in classical Arabic, such as P3465 and Rabat, BNRM 3655.

${ }^{79}$. E.g. in L4044 and Wetzstein II 672.
} 


\section{Bibliography}

Manuscripts

Berlin, Staatsbibliothek, Wetzstein II 672

Cairo, al-Maktaba I-Markaziyya li-I-Makhțūtāt al-Islāmiyya 1169.

Istanbul, Ayasofya 4095

Istanbul, Ayasofya 4213

Istanbul, Ayasofya 4214

London, British Library, Or. 8571

London, British Library, Or. 4044

London, British Library, Or. 3900

Paris, Bibliothèque nationale de France, arabe 3465

Paris, Bibliothèque nationale de France, arabe 3466

Paris, Bibliothèque nationale de France, arabe 3473

Paris, Bibliothèque nationale de France, arabe 3478

Paris, Bibliothèque nationale de France, arabe 5881

Montreal, MacGill University Library, Mc Lennan no. 94

Munich, Bayrische Staatsbibliothek, Cod. arab. 615.

New York, MET 1981.373

Rabat, al-Maktaba al-Malikiyya (BNRM), 3655

Riadh, King Fayșal Library 2536

\section{Primary sources}

Ibrahim Akel, Ahmad ar-Rabbāt: Sa bibliothèque et son rôle dans la réception, diffusion et enrichissement des Mille et une nuits, doctoral thesis, Littératures, Université Sorbonne, Paris Cité, 2016.

Anonymous, A Hundred and One Nights, ed. and trans. by Bruce Fudge, The Library of Arabic Literature, New York: New York University Press, 2016.

Bellino Francesca, "Animal Fables in the Sulwān al-muțā by Ibn Ẓafar al-Siqillī," in: Islamic Sicily: Philological and Literary Essays, ed. M. Cassarino, special issue of QSA N.S. 10 (2015): 103-22.

Cheikho, Louis, La version arabe de Kalīla et Dimnah ou Les fables de Bidpai, Beirut 1905, reprint Amsterdam: Academic Publishers Associated - Philo Press, 1981.

La Fontaine, Jean de, Fables, préface de Jean-Charles Darmon, dossier et notes par Jean-Charles Darmon et Sabine Gruffat, Paris: Librairie Générale de France, 2002.

Ibn al-Muqaffa', Kalila wa-Dimna, ed. Ṭ. Ḥusayn and 'A. 'Azzām, Cairo: Dar al-Ma'ārif, 1941.

Miquel, André, Le livre de Kalila et Dimna ou Fables de Bidpaï, Paris: Klincksieck, 1957, reprinted 1980. 
Schulthess, Friedrich, Kalīla und Dimna. Die altsyrische Version des indischen Fürstenspiegels (Pantschatantra) oder Bidpai's Fabeln, syrischer Text, neu herausgegeben und übersetzt, mit einer Einleitung und kritischen Anmerkungen und Varianten, Berlin, 1911; reprinted with Nöldeke's recension (1911) and Burzoy's preface (1912), Amsterdam: Academic Publishers Associated - Philo Press, 1982; reprinted Berlin: de Gruyter, 2011.

al-Yamanī, Abū 'Abdallāh Muḥammad b. al-Ḥusayn b. 'Umar, Muḍāhāt amthāl Kalīla wa-Dimna bimā ashbahahā min ash'ār al-'arab, ed. M. Yūsuf Najm, Beirut [1961].

Secondary Literature

Basset, Réné, “Notice sur un manuscrit des fables du Kalilah et Dimna," Journal asiatique, série 9, 16 (1900): $360-69$.

Biardeau, Madeleine, Le Mahabharata, 2 vols., Paris: Seuil, 2002.

Bloch, R. Howard, Alison Calhoun, Jacqueline Cerquilini-Toulet, Joachim Küpper, and Jeanette Patterson, eds., Rethinking the New Medievalism, valimore: Johns Hopkins University Press, 2014.

de Blois, François, Burzoy's Voyage to India and the Origin of the Book of Kalilah Wa Dimnah, London: The Royal Asiatic Society, 1990.

Breasted, James H., "The Oriental Institute in Chicago-a Beginning and a Program," American Journal of Semitic Languages and Literatures 38.4 (1922): 233-328.

Brockelmann, Carl, "Kalīla wa-Dimna," Encyclopaedia of Islam, new (second) edition, 4 (1974), pp. 503-6 (first publ. 1929).

Marzolph, Ulrich and Heinz and Sophia Grotzfeld, "Kalīla und Dimna," Enzyklopädie des Märchens, vol. 7, (1993), pp. 888-95.

Cerquiglini, Bernard L'éloge de la variante: Histoire critique de la philologie, Paris, 1986.

Dagenais, John, The Ethics of Reading in Manuscript Culture: Glossing the Libro de buen amor, Princeton New Jersey: Princeton University Press, 1994.

Der Kleine Pauly: Lexikon der Antike in fünf Bänden, 5 vols., Munich: Deutscher Taschenbuch Verlag, 1979.

Dozy, Reinhart, Supplément aux dictionnaires arabes, 2 vols., Leiden: Brill 1881, reprint Beirut: Librairie du Liban 1991.

Gruendler, Beatrice, "Les versions de Kalīla wa-Dimna: und transmission et une circulation mouvantes," in Énoncés sapientiels et littérature exemplaire: une intertextualité complexe, ed. M. Ortola. Nancy: Éditions Universitaires de Lorraine 2013, 385-416.

- - "Stability and Change in Arabic Script," in: The Shape of Script: How and Why Writing Systems Change, ed. S. Houston. Publications of the School of Advanced Research, Santa Fe, 2013, 93-118. 
Hanna, Nelly, In Praise of Books: A cultural history of Cairo's middle class, sixteenth to eighteenth century, Syracuse, New York, 2003.

Hirschler, Konrad, The Written Word in the Medieval Arabic Lands; A social and cultural history of reading practice, Edinburgh: Edinburgh University Press, 2012.

Irwin, Robert, "The Arabic Beast fable," Journal of the Warburg and Courtauld Institutes 55 (1992): 36-50.

Kristó Nagy, István T., La pensée d'Ibn al-Muqaffa': Un “agent double" dans le monde persan et arabe, Paris, Éditions de Paris, 2013.

Lentin, Jérôme, "Middle Arabic," in: Encyclodedia of Arabic Languaga and Linguistics, ed. Kees Versteegh, 5 vols., Leiden : Brill, 2006-9, vol. 3, 215-24.

Mahdi, Muhsin S., The Thousand and One Nights (Alf Layla wa-layla): The classic edition (1984-1994), 2 vols., Leiden: Brill, 2014.

Liebrenz, Boris, "The Library of Ahmad al-Rabbāț: Books and their audiences in 12th to 13th/18th to 19th century Syria," in Marginal Perspectives on early modern Ottoman Culture: Missionaries, travelers, Booksellers, ed. U. Pietruschka and R. Elger, Halle, 2013, pp. 17-59.

Nichols, Stephen, ed. Speculum special issue, "The New Philology," 65.1 (1990).

Nöldeke, Theodor (1879), “Die Erzählung vom Mausekönig und seinen Ministern, Abh. d. Königl. Gesellschaft d. Wissenschaften zu Göttingen, vol. 25/4.

Nöldeke, Theodor, Die Erzählung vom Mäusekönig und seinen Ministern. Ein Abschnitt der Pehlewî-Bearbeitung des altinidischen Fürstenspiegels, Abhandlungen der Deutschen Morgenländischen Gesellschaft 30, 1876, pp. 752-72.

- - "Zu Kalīla wa Dimna," Zeitschrift der Deutschen Morgenländischen Gesellschaft 59 (1905): 794-806, reprinted in Cheikho 1981.

- - "Kalīla und Dimna, syrisch und deutsch: Eine Rezension [of Schulthess's ed. and trans.]" Zeitschrift der Deutschen Morgenländischen Gesellschaft 65 (1911): 578-88, reprinted in Schulthess 1982.

- - Burzôes Einleitung zu dem Buche Kalīla waDimna, übersetzt und erläutert, Schriften der wisss. Ges. in Strassburg, 12. Heft, Strassburg, Trübner, 1912, reprinted in Schulthess 1982.

O'Kane, Bernard, Early Persian Painting: Kalila and Dimna manuscripts of the late fourteenth century, London: Tauris, 2003.

Ruymbeke, Christine van, Kashefi's Anvar-e Sohaili: Rewriting Kalila wa-Dimna in Timurid Herat, Leiden and New York: Brill, 2016 
Sacks, Jeffrey, "The Philological Present: Reading the Arabic Nineteenth Century. Review Essay of Four Books," Journal of Arabic Literature 47 (2016): 169-207.

Sprengling, Martin, “Kalīla Studies," American Journal of Semitic Languages and Literatures 40 (1924): 81-97.

Winternitz, Moris, Geschichte der indischen Literatur, Leipzig: Amelangs Verlag, 1909, vol 1, pp. 259-403.

al-Ya'qūbī, Ta’rīkh al-Ya'qūbì qui dicitur al-Ja'qūbì Historiae, ed. M. T. Houtsma, Leiden 1883, 98-99

al-Ya'qūbī, The Works of Ibn Wāḍị̣ al-Ya'qūbĩ: An English Translation, ed. Matthew S. Gordon, Chase F. Robinson, Everett K. Rowson and Michael Fishbein, Leiden: Brill, 2018, 3 vols.

Zumthor, Paul, Essai de poétique mésdiévale, Paris; Éditions du Seuil, 2000. 